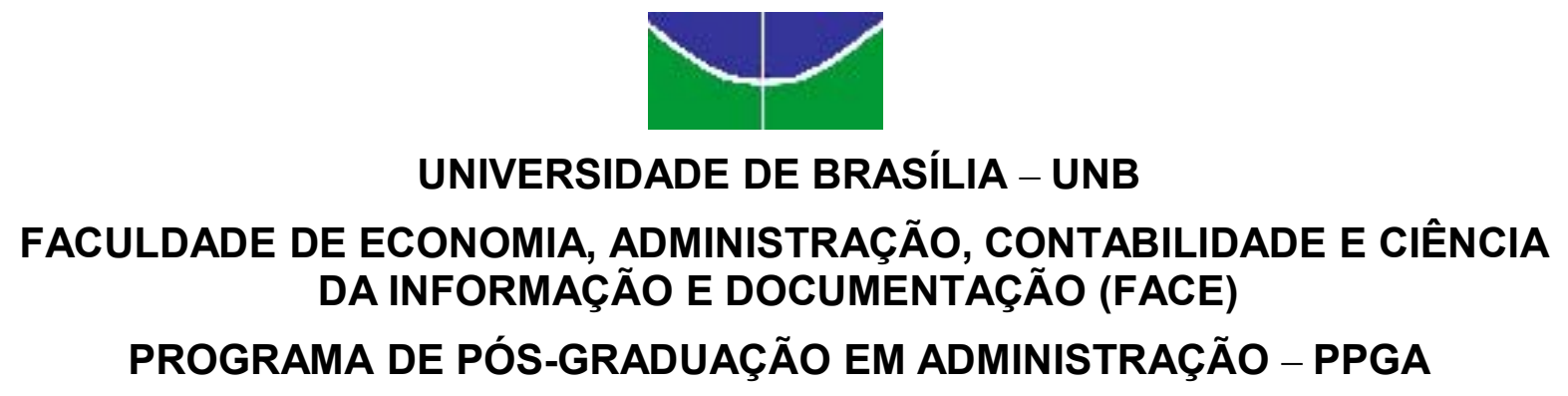

LIDIA CRISTINA RODRIGUES DE ARAÚJO

\title{
ASCENSÃO DO GERENCIALISMO EM UMA EMPRESA PÚBLICA FEDERAL
}

Brasília-DF 
LIDIA CRISTINA RODRIGUES DE ARAÚJO

\section{ASCENSÃO DO GERENCIALISMO EM UMA EMPRESA PÚBLICA FEDERAL}

Monografia apresentada ao Programa de PósGraduação em Administração (PPGA) da Faculdade de Economia, Administração, Contabilidade e Ciência da Informação e Documentação (FACE), da Universidade de Brasília (UnB), como requisito parcial à obtenção do grau de Especialista em Orçamento e Finanças.

Orientador Prof. Dr. Marcus Vinícius Soares Siqueira

\section{Brasília-DF}


A todos os trabalhadores deste país, homens e mulheres que se dispõem a melhorar nosso País através de suas ações e criatividade. 


\section{AGRADECIMENTOS}

A Deus por mais uma oportunidade milagrosa que Ele me deu de crescer.

Ao Mestre com carinho Professor Marcus Vinícius Soares Siqueira, um homem admirável, inteligente e "altamente inquieto". Foi um grande exemplo para mim de que vale a pena lutar pelos nossos ideais. Além, claro, de um excelente orientador.

À professora Fátima Bruno, pela sua disponibilidade e dedicação nas orientações que nortearam nossa pesquisa.

Ao coordenador do Curso, Prof. Eduardo, pela sua prontidão na direção do curso.

A todos os professores do Curso de Orçamento e Finanças, da UnB, pela dedicação, a atenção e competência em disseminar conhecimento.

Aos trabalhadores administrativos e de apoio do PPGA-UnB, pela sua presteza no atendimento.

Aos meus colegas e amigos de turma e de trabalho. Participar com vocês da Pós foi uma experiência excelente e um crescimento profissional.

Aos empregados da Empresa Pública que gentilmente participaram da pesquisa e relataram suas rotinas e expressaram suas percepções sobre seu trabalho. Muito obrigada!

Aos meus pais que souberam me ensinar a confiar em Deus acima de tudo e acreditar que os sonhos de Deus se realizam em nossas vidas e que são infinitamente melhores que os nossos.

Ao meu primo Leonardo Queiroz que sempre me incentivou a estudar.

Em especial quero agradecer ao meu amor, Paulo Roberto, que não mediu esforços para fazer a revisão deste trabalho e que pacientemente me apoiou nos momentos em que mais precisei. 
"Meu pai ensinou-me a trabalhar; não me ensinou a amar o trabalho". Abraham Lincoln 


\section{RESUMO}

O presente trabalho tem como objetivo identificar e analisar a presença e ascensão do gerencialismo no setor público, investigando o fenômeno em uma empresa pública federal. Tem como objetivos específicos discutir o processo de modernização da Administração Pública; caracterizar as influências do gerencialismo no setor público a partir da literatura e verificar a existência e a ascensão do gerencialismo no Programa Gerencial da empresa. A reforma do Estado fomentou na década de 90 a administração gerencial e trouxe para a administração pública uma forte orientação à produtividade e eficiência no atendimento ao cidadão. A busca por resultados é a linha mestra de sua ideologia. Portanto, gerencialismo é toda e qualquer influência das empresas privadas sobre o setor público A classificação da pesquisa baseia-se em dois critérios básicos: quanto aos fins e quanto aos meios. A pesquisa aplicada é qualitativa e, no que diz respeito aos fins, exploratória e descritiva. Quanto aos meios a pesquisa foi bibliográfica, de campo e documental: Bibliográfica porque para a fundamentação teórica foram realizadas pesquisas sobre os seguintes assuntos: Modernização do Estado, Gestão Pública, Gerencialismo, Ética no Setor público, Motivação no Trabalho e Discurso Organizacional. De campo, porque serão realizadas entrevistas individuais e Documentais, porque foram realizados investigações no programa de treinamentos gerenciais - sítio com treinamento gerencial em EAD e outros documentos internos da organização. O resultado da pesquisa levou a divisão em três categorias perceptíveis na organização: Forte Orientação para Resultados e Obsessão por Produtividade, Cultura do Management e Comprometimento Afetivo e Ética de Negócios e Crença Excessiva na Tecnologia e Ferramentas de Gestão. Percebeu-se nitidamente a presença e a ascensão do modelo gerencialista na empresa pública federal, objeto da pesquisa, que se caracteriza no alinhamento dos objetivos da empresa com os treinamentos oferecidos, utilizando recursos de uma empresa privada para dar os treinamentos com forte incentivo à cultura do management. Verificou-se que o recurso humano na administração gerencial é um instrumento para se chegar a resultados. Este trabalho pode contribuir para a discussão de uma nova gestão pública.

Palavras-chave: Modernização do Estado; Gestão Pública; Gerencialismo; Discurso Organizacional; 


\section{LISTA DE FIGURAS}

Figura 1 - Setores do Estado, forma de propriedades, administração e instituições. 


\section{LISTA DE TABELAS}

Tabela I - Elementos da Fundamentação Teórica e da Pesquisa de Campo..............................46

Tabela II - Elementos da Fundamentação Teórica e da Pesquisa Documental .......................47 


\section{SUMÁRIO}

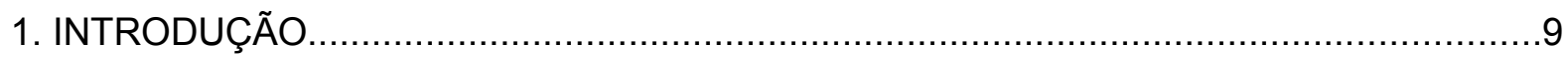

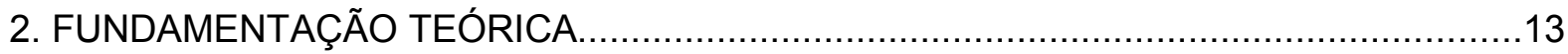

2.1 A Modernização da Administração Pública no Brasil............................................13

2.1.1 Administração Burocrática...................................................................... 13

2.1.2 Administração Pública Gerencial................................................................. 16

2.2 Gerencialismo na Administração Pública...........................................................19

2.2.1 Gerencialismo no Setor Público................................................................ 19

2.2.2 Efeitos do Gerencialismo no Setor Público................................................22

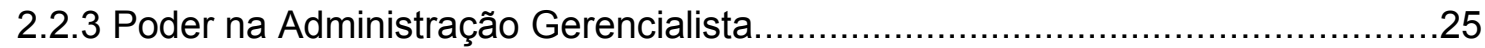

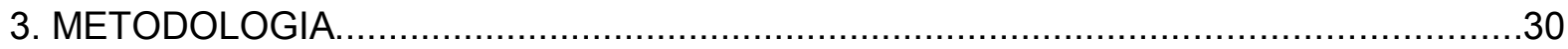

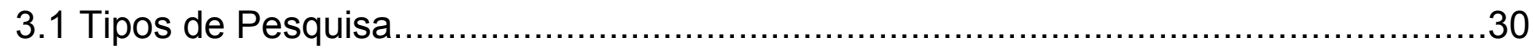

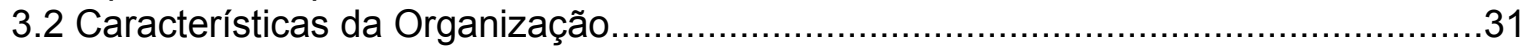

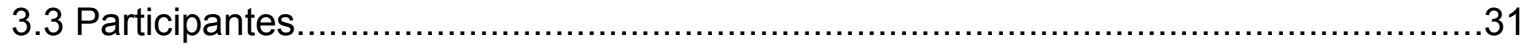

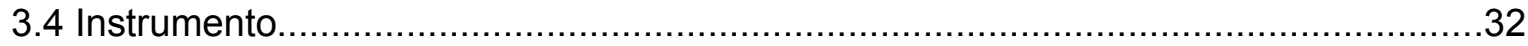

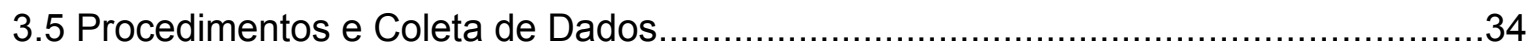

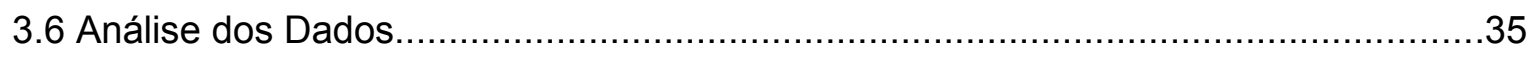

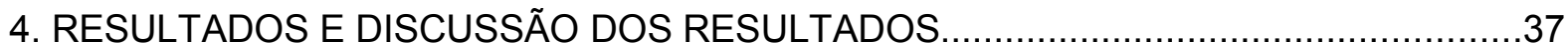

4.1 Forte Orientação para Resultados e Obsessão por Produtividade...........................37

4.2 Cultura do Management e Comprometimento Afetivo.............................................40

4.3 Ética de Negócios e Crença Excessiva na Tecnologia e Ferramentas de Gestão.....44

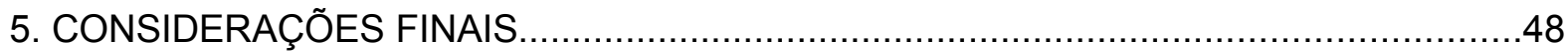

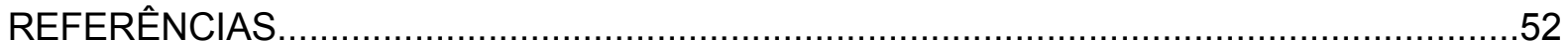




\section{INTRODUÇÃO}

A reforma do Estado fomentou, na década de 90, a administração gerencial e trouxe para a administração pública uma forte orientação à produtividade e eficiência no atendimento ao cidadão. A busca por resultados é a linha mestra de sua ideologia. Práticas de gestão da iniciativa privada foram incorporadas ao setor público como único e verdadeiro caminho para solução dos serviços públicos, tais como: programas de excelência e qualidade total, avaliação de desempenho e trabalho em equipe apoiado por consultorias de empresas privadas. O gestor público foi sobrecarregado de premissas a serem seguidas para que alcançasse o sucesso profissional e resultados econômicos para o órgão público.

Segundo Chanlat (2002, p.1) gerencialismo é toda e qualquer influência das empresas privadas sobre o setor público. "A hegemonia da empresa privada como modelo organizacional eficiente e do mercado como mecanismo de regulação das trocas, têm de fato influenciado profundamente $[\ldots]$ ". toda a sociedade.

De acordo com Paula (2005) o gerencialismo constitui-se na convicção de que o desenvolvimento da sociedade ocorre pela alta produtividade econômica, aproveitamento de tecnologias e de ferramentas de ponta para melhor desempenho do trabalho; o gerente tem o direito de administrar e o management desempenha um papel importantíssimo nos programas e implementação de melhorias contínuas no processo de produtividade.

Esse novo modo de administrar fez nascer nas organizações uma ideologia empreendedorista fundamentada em valores e condutas que visam garantir o controle, a eficiência e a produtividade. A centralidade no culto da excelência fez com que o imaginário social ficasse recheado de fantasias de oportunidades e crescimento pautados no individualismo.

O movimento gerencialista cooperou, e muito, para a concepção da indústria do management, que tem como definição um conjunto de pressupostos internalizados pelas empresas, tais como: crença em uma sociedade de mercado livre, visão do indivíduo como auto-empreendedor, culto da excelência, culto a símbolos, como o "gerente herói", culto a figuras, como as palavras: inovação, sucesso, excelência e a crença em ferramentas gerenciais que facilitem a tomada de decisão nas organizações (PAULA, 2005). 
Esse sistema infiltrou-se em todos os setores da sociedade, tais como: universidades, hospitais, administração social e entidades sem fins lucrativos, tendo o gestor como ponto central da sociedade capitalista.

Para a compreensão da presença e ascensão do gerencialismo no setor público, são indispensáveis os fatos históricos que corroboraram para a evolução desse sistema, fatos esses que foram do liberalismo aos movimentos neoconservadores.

Paes de Paula (2005) afirma que ao longo do século XVIII, a estruturação do Estado Liberal caracterizou-se pela postura de responsável pela ordem e segurança nacional, restringindo sua atuação na defesa nacional, arrecadação e diplomacia. O Estado era limitado e indiferente à área social e econômica. O pensamento liberal defende o Laissezfaire ou a não intervenção do Estado no mercado, os quais ficavam sobre as próprias forças sociais.

O modelo de Estado módico tem seu final logo após a Primeira Guerra Mundial e a Revolução Russa, desmoronando definitivamente na década de 30 , pois a falta de uma política social gerou no mercado livre uma insuficiência de demanda, acarretando uma crise generalizada e abriu caminho para um Estado intervencionista. Nessa nova visão surgiu o Estado do Bem-Estar Social (Welfare State), em especial na Europa (MIRANDA JUCÁ, 2002).

De acordo com MIRANDA JUCÁ (2002) constatou-se que em paralelo com o crescimento exagerado do Estado, a partir da segunda metade do século XX, uma intensa alteração no sistema econômico mundial contribuiu para o colapso do Governo. A rapidez do desenvolvimento tecnológico e a redução dos custos foram fatos que levaram a uma nova dinâmica de capitalismo internacional. A globalização fez aumentar a competição e impôs uma dupla pressão aos Estados: proteger a sociedade da concentração de renda e realizar com maior eficiência as atividades públicas, para que haja alivio das pressões sobre as empresas nacionais e promover a concorrência no mercado internacional.

Nesse novo arcabouço de uma economia globalizada e de intensa competição, a crise do Estado caracterizou-se em três vieses: crise fiscal, caracterizada pela perda de credibilidade por parte do Estado e pelo aumento do déficit financeiro, incapacitando-o de realizar as políticas públicas; crise do modo estatizante de intervenção do Estado, o que 
significa a exaustão do Welfare State e dos países comunistas; e crise do modelo burocrático de gestão pública, marcado pelos altos custos e baixa qualidade dos serviços púbicos (MIRANDA JUCÁ, 2002).

De Estado Intervencionista, que no início do século XVIII foi assinalado como o responsável pelo desenvolvimento, converteu-se em empecilho ao crescimento econômico social, e consequentemente toda essa crise demandou imediatas alterações no seu modelo. Nesse contexto, surge na década de 80 um movimento mundial de reformas dos Estados.

Nesse ponto de vista, a "nova administração pública" origina-se na teoria da escolha pública e no neoliberalismo, tendo por base os exemplos dos governos de Margaret Thatcher, na Inglaterra e de Ronald Reagan, nos Estados Unidos da América, em fins da década de 70 e começo dos anos 1980 (PAULA, 2005, p.36).

De acordo com Paes de Paula (2005, p.53) o movimento "reinventando o governo" está baseado nos princípios gerencialista: descentralização do aparelho de Estado, as privatizações das organizações estatais e a terceirização do serviço público.

A crítica à administração burocrática no Brasil tornou-se mais acirrada a partir do governo do presidente Fernando Henrique Cardoso com a criação do Ministério da Administração e reforma do Estado (MARE), sob a direção de do Ministro Luiz Carlos Bresser Pereira. O novo ministério trouxe para a reforma conceitos dos modismos europeu e americano, implantando assim a gestão de Qualidade Total e reengenharia em seu governo.

Nesse contexto de práticas gerencialistas no setor público é que pretendo realizar minhas pesquisas.

As organizações públicas são alvos das interferências diretas das empresas privadas, uma vez que estas são contratadas para realizarem consultorias e treinamentos para gerentes e funcionários. Influenciam fortemente a cultura da organização, com conceitos e práticas do setor privado. Essas práticas muitas vezes não se aplicam ao setor público pela própria diferença da natureza do trabalho.

Buscaremos responder à seguinte pergunta: Quais são os indícios da presença e da ascensão do gerencialismo em uma instituição do setor público? 
A pergunta de pesquisa considera, particularmente, a influência exercida por consultorias nos programas de desenvolvimento gerencial na organização.

As pesquisas feitas acerca do fenômeno do gerencialismo no setor público caracterizam-se, predominantemente, por estudos relacionados à investigação histórica da modernização do Estado e suas conseqüências (PAES DE PAULA, 2002), sua difusão nas organizações, mudando o comportamento do funcionalismo público e os impactos dessa mudança no contexto organizacional (CHANLAT, 2002). A influência das empresas privadas sobre o setor público trouxe conseqüências desastrosas para o ser humano que trabalha na organização. Atrás de um véu de pragmatismo, a gestão construiu toda uma ideologia na busca desenfreada pelo lucro. "Administrar" tornou-se a voz de comando para os gestores, instalando assim um novo poder gerencialista

O objetivo geral deste estudo foi o de identificar e analisar a presença e ascensão do gerencialismo no setor público investigando o fenômeno em uma empresa pública.

Com objetivos específicos, pretende-se: discutir o Processo de modernização da Administração Pública; caracterizar as influências do gerencialismo no setor público a partir da literatura em uma empresa pública e verificar a existência e a ascensão do gerencialismo no Programa Gerencial da empresa.

Percebe-se na literatura uma crescente atenção a este tema, sobre vários enfoques. Considerando o enfoque multidisciplinar do gerencialismo, suas causas e efeitos vêm sendo estudados pela ciência da Administração, Sociologia, Psicologia e da Economia. O assunto em questão é extremamente relevante para as organizações governamentais como um processo de repensar uma nova gestão como objeto de estudo e trabalho, para a construção uma ideologia do bem comum, e não pautada no individualismo e na competição. 


\section{FUNDAMENTAÇÃO TEÓRICA}

\subsection{A Modernização da Administração Pública no Brasil}

\subsubsection{Administração Burocrática}

A reforma administrativa é um processo contínuo na história da administração pública, pois em toda extensão de sua evolução, nos discursos dos governantes está a necessidade de uma administração mais moderna e eficiente, num choque permanente de duas forças antagônicas: a vigente com suas vulnerabilidades e deficiências e a que está brotando com as novidades que o tempo exige. Neste contexto as palavras governabilidade e governança aparecem com força total. Segundo Bresser Pereira (1998):

Governabilidade é a capacidade de governar derivada da relação de legitimidade do Estado e do seu governo com a sociedade civil; a governança pode ser definida como a capacidade financeira e administrativa para pôr em prática, de forma eficiente, as decisões governamentais (BRESSER PEREIRA, 1998, p.4).

Segundo Bresser Pereira (1998) o processo de modernização do Estado é um tema amplo e envolve aspectos políticos - os que se relacionam com a promoção da governabilidade, econômicos e administrativos - aqueles que visam a aumentar a governança. Ainda segundo o autor, a reforma é a capacidade efetiva de que governo dispõe de transformar suas políticas em realidade. Tendo como base essa premissa, percebe-se no decorrer da história uma busca constante de reforma e consequentemente de transformação das políticas públicas em uma realidade que melhore a qualidade de vida do cidadão e lhe dê maior segurança.

De acordo com Bresser Pereira, a reforma que ocorreu no século XIX, foi um grande progresso, levando ao surgimento da administração pública burocrática em substituição às formas patrimonialistas de administrar o Estado. Prossegue afirmando que:

A característica que definia o governo nas sociedades pré-capitalistas e prédemocráticas era a privatização do estado, ou a interpermeabilidade dos patrimônios públicos e privados. Patrimonialismo significa a incapacidade ou a relutância do príncipe de distinguir entre o patrimônio público e seus bens privados (BRESSER PEREIRA, 1998, p.26).

Ainda segundo o autor a administração do Estado pré-capitalista era uma administração patrimonialista. Com o aparecimento do Capitalismo e da Democracia, foi 
instituída a diferença marcante entre a res republica e bens privados. A democracia e a administração burocrática surgiram como as instituições fundamentais à proteção do patrimônio público contra a privatização do Estado (PEREIRA BRESSER, 1998).

\begin{abstract}
Democracia é o instrumento político que protege os direitos civis contra a tirania, que assegura os direitos sociais contra a exploração e que afirma os direitos públicos em oposição ao rent-seeking. Burocracia é a instituição administrativa que usa como instrumento para combater o nepotismo e a corrupção - dois traços inerentes à administração patrimonialista -, os princípios de um serviço público profissional e de um sistema administrativo impessoal, formal e racional. (BRESSER PEREIRA, 1998, p.26).
\end{abstract}

Seguindo o raciocínio de Bresser Pereira (1998), a administração burocrática clássica, surgiu na Europa, no final do século XVIII, na América no inicio do século XIX, no Brasil, em 1936, com a reforma administrativa promovido por Maurício Nabuco e Luis Simões Lopes. É a burocracia que Max Weber implementou, fundamentada no princípio do mérito pessoal.

Confirmando a citação acima de Bresser Pereira (1998), a administração pública burocrática foi a opção que cabia na época para substituir a administração patrimonialista, na qual o patrimônio público e o privado eram confundidos e o Estado era entendido como propriedade do Rei. De fato o nepotismo, o empreguismo e a corrupção, era o padrão seguido por todos que estavam no poder. E esse tipo de administração segundo Bresser (1998, p.29) "era incompatível com o capitalismo industrial e as democracias parlamentares, que surgem do século XIX. É fundamental para o capitalismo a distância entre Estado e mercado".

Ultrapassada a idéia patrimonialista, começou-se a disseminar a lógica weberiana de administração racional-legal, ou seja, uma administração burocrática dentro dos padrões do capitalismo.

De acordo com Miranda Jucá (2002, p.6), inaugura-se o modo de administrar tendo como base a "impessoalidade, o formalismo, a divisão de trabalho, a hierarquia funcional, a competência técnica baseada em um sistema de mérito e ainda um rígido controle de procedimentos adotados pelo administrador público", esforço esse para tentar diminuir a corrupção e o nepotismo.

Entretanto, segundo Bresser Pereira (1998), o projeto com pressupostos baseados na eficiência, na pratica não se mostrou sustentável: 
No momento em que pequeno Estado liberal do século XIX deu definitivamente lugar ao grande Estado social e econômico do século XX, verificou-se que não garantia nem rapidez, nem boa qualidade nem custo baixo para os serviços prestados ao público. Na verdade, a administração burocrática é lenta, cara, autoreferida, pouco ou nada orientada para o atendimento das demandas dos cidadãos. (BRESSER PEREIRA, 2005, p.241)

Nessa perspectiva, no Brasil, enquanto predominava um Estado pequeno, com funções restritas: "garantir a propriedade e contratos, o problema da eficiência não era essencial" (BRESSER PEREIRA, 1998). "Mas no "momento em que o Estado se transformou no grande Estado social e econômico do século $\mathrm{XX}$, assumiu um número crescente de serviços sociais e de papéis econômicos” (BRESSER PEREIRA, 2005). O problema da eficiência tornou-se essencial. Nessa perspectiva, a rigidez do protocolo burocrático não conseguiu resistir aos avanços tecnológicos e ao mundo globalizado. A gestão da máquina pública passou a exigir uma forma de administrar mais ágil, descentralizada, e mais voltada para o controle dos resultados.

A crise fiscal dos anos 70 e 80, caracterizada pela incapacidade do Estado em superar o problema da poupança pública negativa e pela falta de recursos para a introdução e desenvolvimento de novas políticas governamentais, nada mais representou senão uma crise de governança, na medida em que imobilizava o Poder Público, obstando-o de cumprir seus deveres sociais e contribuindo ainda mais para a precarização dos serviços públicos (JUCÁ, 2002). E, em conformidade com Bresser Pereira (1999, p.21), as conseqüências do resquício do "patrimonialismo e do enrijecimento burocrático misturados, geraram um alto custo e a baixa qualidade da administração pública brasileira".

Essa crise de governança, aliada à rigidez e ineficiência da máquina administrativa, tornou premente a implantação de um novo modelo de administração pública, capaz de melhor atender as demandas sociais. É aí que ressurge o tema da Reforma Administrativa.

Na realidade, conforme Abrucio (2005, p.175) “o sentimento antiburocrático aliavase à crença, presente em boa parte da opinião pública, de que o setor privado possuía o modelo ideal de gestão". Essa idéia contrária à burocracia estatal e favorável aos ideais da iniciativa privada predominou, e é nesse contexto que surge a chamada administração gerencial. 


\subsubsection{Administração Pública Gerencial}

Conforme Kettl (1998), na década de 80, em todo mundo começou um completo movimento de reforma do setor público. Praticamente todos os governos estavam investindo em tentativas de modernizar, aplicando os princípios da eficiência e da eficácia à administração pública. O movimento para redução do Estado estava presente e em crescimento no mundo inteiro.

\footnotetext{
Estados que têm grandes aparelhos de administração pública, como Suécia, deram início à reforma praticamente ao mesmo tempo em que os Estados nos quais o setor governamental é muito menor, como o Reino Unido. Da coréia ao Brasil, de Portugal à Nova Zelândia, a reforma do setor governamental tornou-se um fenômeno verdadeiramente universal. (KETTL, 2005, p. 76).
}

No instante que o Governo divulga o plano de reformas a pressão por resultados é inevitável. Para que se consolide o apoio político é importante o sucesso em curto prazo. As premissas da proposta de reforma administrativa era que funcionasse melhor e que custasse menos (KETTL, 1998).

Dentre os inúmeros mecanismos para se promover a reforma administrativa de acordo com Kettl são: "limites das dimensões do setor publico, privatização, comercialização de órgãos públicos, descentralização, desconcentração do governo central e uso de mecanismos típicos de mercado". (KETTL, 2005 p. 79). O plano era substituir a autoridade e a rigidez pela flexibilidade; a atenção à estrutura e aos procedimentos pela melhoria do processo. Mais do que isso, os reformadores fundamentaram seu plano de reforma no desgaste progressivo da hierarquia burocrática despótica que dominara por tanto tempo na gestão pública (Kettl, 2005).

A Nova Zelândia e o Reino Unido colocaram em prática literalmente o que pregam essas teorias: fizeram uma reengenharia de negócio e agressivamente privatizaram empresas públicas. Terceirizaram várias atividades que estavam sob o controle do Estado. A atividade dos órgãos públicos de controle de produção foi transformada em aferição dos resultados dessa atividade. Foram criados mecanismos novos para avaliar, no mercado, os programas administrados por órgãos públicos, e mais, que os administradores públicos ingressassem na competição do mercado para os próprios cargos que ocupavam. Inseriram sistemas amplos de controle dos gastos públicos. Todos esses sistemas, integrados, tinham 
como condição principal modificar o sistema de incentivos para "fazer os gerentes públicos gerenciar" (KETTL, 2005 p. 83).

A reforma da administração pública no Brasil, inserida por Bresser Pereira, no governo de Fernando Henrique, foi planejada sobre três dimensões conforme Bresser (1998): 1- uma dimensão institucional-legal, onde modificaram e criaram leis e instituições; 2- uma dimensão cultural, baseada na mudança dos valores burocráticos para os gerenciais e 3 - uma dimensão-gestão.

Ainda nessa perspectiva, na dimensão institucional-legal, foi preciso a modificação de todo o sistema legal. A dimensão cultural de todo o debate que houve em 1995 sobre a reforma constitucional do capítulo da administração pública foi um processo de mudança de cultura. E, finalmente, a dimensão-gestão foi a mais difícil. Trata-se aqui de colocar em prática as novas idéias gerenciais, trazidas do setor privado, num universo completamente diferente e com a promessa de oferecer à sociedade um serviço público efetivamente mais barato, melhor controlado, e com mais qualidade. Para isto foram criadas as agências autônomas, ao nível das atividades exclusivas de Estado, e das organizações sociais no setor público não-estatal. Inicialmente as novas práticas administrativas foram introduzidas com o apoio do Ministério da Administração Federal e Reforma do Estado (Mare), que foi criado para formular e implementar essa política pública no primeiro governo Fernando Henrique Cardoso (1995-1998), mas depois as próprias unidades foram sendo transformadas (BRESSER PEREIRA, 1999).

As principais características do modelo de administração gerencial:

a) orientação do Estado para o cidadão usuário ou cidadão-cliente;

b) ênfase no controle dos resultados, através de contratos de gestão (ao invés de controle de procedimentos);

c) fortalecimento e aumento da autonomia da burocracia estatal, organizada em carreiras ou "corpos" de Estado, e valorização de seu trabalho técnico e político de participar, juntamente com os políticos e a sociedade, da formulação das políticas públicas;

d) separação entre as secretarias formuladoras de políticas públicas, de caráter centralizado, e as unidades descentralizadas, executoras dessas políticas;

e) distinção entre dois tipos de unidades descentralizadas: as agências executivas, que realizam atividades exclusivas do Estado, por definição monopolista, e os serviços sociais e científicos de caráter competitivo, em que o poder do Estado não está envolvido;

f) transferência para o setor público não-estatal dos serviços sociais e científicos competitivos;

g) adoção cumulativa, para controlar as unidades descentralizadas, dos mecanismos (1) de controle social direto, (2) do contrato de gestão em que os indicadores de desempenho 
sejam claramente definidos e os resultados medidos, e (3) da formação de quasemercados em que ocorre a competição administrativa;

h) terceirização das atividades auxiliares ou de apoio, que passam a ser licitadas competitivamente no mercado (BRESSER PEREIRA, 1999, p.58).

A proposta de reforma do aparelho do Estado parte da existência de quatro setores dentro do Estado: (1) o núcleo estratégico do Estado, (2) as atividades exclusivas de Estado, (3) os serviços não-exclusivos ou competitivos, e (4) a produção de bens e serviços para o mercado.

Figura 1: Setores do Estado, Formas de Propriedade e de Admini stração

F ORMA DE PROPRIE DADE

\begin{tabular}{|c|c|c|c|c|c|}
\hline & Estatal & $\begin{array}{l}\text { Pública } \\
\text { Não- } \\
\text { Estatal }\end{array}$ & Privada & Burocrática & Gerencial \\
\hline $\begin{array}{l}\text { NÚCLEO } \\
\text { EST RATÉG ICO } \\
\text { Legislativo, Judiciário, } \\
\text { Presidência, Cúpula dos } \\
\text { Ministérios }\end{array}$ & & & & & \\
\hline $\begin{array}{l}\text { ATIVIDADES } \\
\text { EXCLUSIVAS } \\
\text { Polícia, Regulamentação } \\
\text { Fiscalização, Fomento, } \\
\text { Seguridade Social Básica }\end{array}$ & & & & & \\
\hline $\begin{array}{l}\text { SERVIÇOS } \\
\text { NÃO-EXCLUSIVOS } \\
\text { Universidades, Hospitais, } \\
\text { Centros de Pesquisa, } \\
\text { Museus }\end{array}$ & Fub licização & & & & \\
\hline $\begin{array}{l}\text { PRODUÇÃO PARA O } \\
\text { MERCADO } \\
\text { Empresas Estatais }\end{array}$ & & Privatização & & & \\
\hline
\end{tabular}

Figura 1: Setores do Estado, Formas de Propriedade e de Administração

Fonte: Bresser Pereira (1999, p.41).

Por fim Bresser Pereira (1999) diz que no final de 1995 havia uma convicção não apenas de que a reforma constitucional tinha ampla condição de ser aprovada pelo Congresso. Era também fundamental para o ajuste fiscal dos estados e municípios, promover a transição de uma administração pública burocrática, lenta e ineficiente, para uma administração pública gerencial, descentralizada, eficiente e voltada para o atendimento dos cidadãos. Administradores de empresas privadas foram convidados a 
dirigir órgãos públicos e a abertura de grande contratação de consultorias de empresas do setor privado para o setor público. É a administração pública gerencial que surgiu inspirada nos avanços realizados pela administração de empresas.

\subsection{Gerencialismo na Administração Pública}

\subsubsection{Gerencialismo no Setor Público}

Influenciado pelo movimento reformista do contexto mundial, o Estado brasileiro também ingressou na "onda" das reformas estatais. O movimento "reinventando o governo" segundo Paes de Paula (2005, p.53), "está diretamente relacionado com a emergência da indústria do management: escolas de administração, as empresas de consultorias, gurus empresariais e a mídia de negócios". Ainda de acordo com a autora:

Durante os anos 1980 e 1990, os agentes da indústria do management ajudaram a consolidar o movimento gerencialista por meio de um discurso composto pelos seguintes elementos: a crítica das organizações burocráticas e a valorização da cultura do management e a conversão de técnicas e práticas administrativas em "modismo gerenciais". (PAES DE PAULA, 2005, p. 54).

A união entre planejamento, descentralização e empreendedorismo fundamentaram a crítica às organizações burocráticas e consequentemente ao fortalecimento do movimento gerencialista que se baseia em produtividade, tecnologia, planejamento e administração.

Segundo PAES DE PAULA (2005) o culto a excelência, oriundo dos Estados Unidos e com os mesmos padrões do empreendedorismo britânico, passou a fazer parte da cultura do management, criando assim "um novo imaginário organizacional e social" (PAES DE PAULA, 2005) onde dentro das organizações formaram "gurus, gerentes-heróis e fórmulas infalíveis de gestão"(PAES DE PAULA, 2005 p.54).

Dentre as premissas básicas que fundamentaram o movimento "reinventando o governo", independentemente do País que adotou tais práticas estão: técnicas administrativas do setor privado, foco na eficiência, privatização do setor público e transferência de responsabilidades públicas para a sociedade (PAULA). Com esse discurso foi aberto um canal de competição entre o setor privado e o público no que diz respeito à prestação de serviços. 
Segundo Chanlat (2002, p.3), a supremacia das empresas privadas como protótipo organizacional eficiente e do "mercado como mecanismo de regulação das trocas influenciou fortemente todas as organizações estatais nas suas ações públicas e políticas, seus programas e estrutura e conseqüentemente em sua cultura".

De acordo com Chanlat (2002, p.3) as organizações públicas passaram então à "descrição, explicação e interpretação a partir das categorias da gestão privada" (CHANLAT, 2002). Ainda, segundo o autor, o modo de se expressar como, por exemplo, o uso das palavras gestão, gerir, manager tornou-se usual nas organizações públicas e na própria linguagem do individuo. Com relação à cultura organizacional, é notável o uso de premissas pregadas pelas empresas privadas agora como pilares públicos "(eficiência, produtividade, desempenho, competência, liderança empresarial, qualidade total, cliente, produto, marketing, excelência, reengenharia etc.)" (CHANLAT, 2002).

Segundo Moreira Neto (1998, p.43), a Emenda Constitucional nº 19, promulgada em de quatro de junho de 1998, à Constituição de 1988, que, entre outros assuntos, "modifica o regime e dispõe sobre princípios e normas da Administração Pública, servidores e agentes políticos, controle de despesas e finanças públicas", surgiram como um marco da transformação da administração pública burocrática para a gerencial, no contexto mais amplo da reforma do Estado brasileiro. Ainda na mesma perspectiva

\begin{abstract}
no plano doutrinário há dois referenciais que a destacam: a nova redação dada ao artigo 37, caput, que acrescenta aos princípios administrativos já expressos, legalidade, impessoalidade, moralidade e publicidade, também a eficiência, e o novo parágrafo $8^{\circ}$, acrescido ao mesmo artigo, que admite a ampliação da autonomia gerencial, orçamentária e financeira dos órgãos e entidades da administração direta e indireta através de contratos de desempenho, a serem firmados entre seus respectivos administradores e o Estado, em que serão fixadas metas de eficiência a serem alcançadas. (MOREIRA NETO, 1998, p.43).
\end{abstract}

Com relação à autonomia gerencial, cabe ressaltar que a Emenda à Constituição instituiu um contrato administrativo singular, em que as partes são, de um lado, "os administradores" de órgãos e de entidades da administração pública direta ou indireta, portanto, pessoas físicas, e, de outro, “o Poder Público”, ou seja, pessoas jurídicas. Esta nova ferramenta "pretende estabelecer um regime de motivação em que o mérito não reside no cumprimento de rotinas e processos, mas no atingi mento de metas claras e prefixadas". (MOREIRA NETO, 1998, p.43). 
O conceito de competitividade do setor público gerou uma novidade dentro do contexto da administração pública, e para a gestão dos interesses públicos, girando em torno de dois princípios fundamentais: a ética e a eficiência. Com relação à ética, segundo Moreira Neto,

\begin{abstract}
uma boa síntese de deveres funcionais nela centrados se encontra no documento denominado "Sete Princípios da Vida Pública", constante do conhecido Relatório Nolan, apresentado pelo Primeiro Ministro Britânico ao Parlamento em maio de 1995. São eles: interesse público, integridade, objetividade, responsabilidade (accountability), transparência, honestidade e liderança (MOREIRA NETO, 1998, p.43).
\end{abstract}

A finalidade da administração deve ser o interesse público, e deverá ser sempre perseguido com impessoalidade pelos agentes dele encarregados. Mas, conforme Paes de Paula:

O Estado contemporâneo é um Estado gerencial, ou seja, um corpo político e administrativo permeado por movimentos simultâneos de descentralização e recentralização e também por relações competitivas, tanto horizontais como verticais, nas quais o poder é flexibilizado e se encontra disperso." (PAES DE PAULA, 2005, p.98).

De acordo com Paes de Paula a reforma na teoria é de uma beleza inquestionável. $\mathrm{Na}$ prática, porém, exerce o poder de uma forma sutil de controle com um déficit democrático, pois, apesar de toda uma homilia de democratização, as decisões estratégicas são verticalizadas, vindas de cima para baixo, sem abertura da participação da comunidade decisões tomadas pelos administradores das organizações públicas e privadas. A representabilidade dos políticos e dos cidadãos é sabotada “e, em decorrência a resistência da sociedade organizada, se enfraquece e seu envolvimento no projeto de reconstrução social fica comprometido." (PAES DE PAULA, 2005, p.100).

Nesse raciocínio Paes de Paula diz que no nível do discurso a reforma do Estado é participativa, mas centralizadora no que se refere "aos processos decisórios, à organização das instituições políticas e à construção de canais de participação popular" (PAES DE PAULA, 2005). Quando ponderamos sobre a estrutura governamental depois da reforma verifica-se a concentração do poder no núcleo estratégico. 
Dá-se total credibilidade à eficiência do controle social, mas dá autoridade para a construção das políticas públicas aos burocratas, onde o privilégio exclusivo das decisões foi delegado às secretarias.

De acordo com Paes de Paula (2005), o projeto das agencias e organizações sociais, não atingiu o objetivo almejado e conseqüentemente níveis aceitáveis de eficiência e atendimento do interesse do público.

\subsubsection{Efeitos do Gerencialismo no Setor Público}

O setor público tem particularidades e especificidades que o setor privado desconhece completamente. São dois mundos diferentes e, porque não dizer, antagônicos entre si. Seus objetivos e metas convergem em sentidos opostos.

Segundo Paes de Paula (2005) a busca desenfreada pelo lucro, a ênfase no individualismo e na competição é uma característica marcante do setor privado, e em contrapartida, o setor público visa arrecadar para gastar em favor de uma melhor qualidade de vida do cidadão. Essa disparidade de ideologia tem sido negada nas últimas décadas. Mas está nascendo aos poucos, muito timidamente, uma oposição ao gerencialismo que tomou conta da administração pública através da reforma do Estado, com a implantação da administração gerencial no setor público. Essa oposição é tímida, mas primordial para a busca de uma nova gestão no setor público.

Na maioria dos países que adotaram essa prática aconteceram no setor público cortes orçamentários e privatizações e, nesse contexto, o fator humano foi totalmente negligenciado. Na perspectiva de Chanlat (2005)

\footnotetext{
nesse novo ambiente, o funcionário deve ser ao mesmo competitivo e eficiente e dispor das mesmas aptidões que os empregados do setor privado, e nesse novo modelo de gerenciamento público, "a gestão do setor público deve ser similar à do setor privado" (KUDRYCK, ano, apud CHANLAT, 2002, p.2).
}

A reforma da administração pública, no que diz respeito à questão humana, isto é, a gestão de pessoas, se concentrou em questões de redução de custos, extinção de órgãos e funções, corte de pessoal, mudança no regime de contratação e divulgação de uma imagem 
negativa do funcionalismo público para que a sociedade se colocasse contrária ao modelo vigente - burocrático.

\begin{abstract}
A política de recursos humanos proposta pelo MARE mantém a diferenciação entre os escalões governamentais, pois tenta fortalecer a alta burocracia por meio do projeto de contratação e formação de especialistas, e procura isentar o Estado do recrutamento, formação e qualificação dos escalões inferiores, que seriam idealmente transferidos para a responsabilidade do setor privado e não-estatal" (PAES DE PAULA, 2005. p. 45).
\end{abstract}

Ainda conforme Paes de Paula (2005), a formação da responsabilidade pública dos servidores foi comprometida por três fatores: "a ênfase na automatização dos procedimentos, o foco na satisfação do cidadão-cliente e a falta de uma carreira pública estruturada" (PAES DE PAULA, 2005, p. 45).

O Ministério de Administração da Reforma do Estado implantou alguns programas, destaca De Paula (2005), onde um deles foi o Programa de Qualidade e Participação, cópia fiel do programa praticado pela iniciativa privada - Programa de Qualidade Total, com o objetivo de facilitar a mudança cultural dos servidores para aceitação do novo modelo de gestão. O escopo do programa era:

- $\quad$ satisfação do cliente;

- constância de propósito;

- melhoria contínua;

- gestão participativa e

- valorização dos servidores.

Continuando no raciocínio da autora, a ideologia gerencialista pretendia com a implantação dos programas incentivar a participação, capacitar técnica e gerencialmente, motivar e remunerar de acordo com o desempenho os servidores públicos, mas não tiveram o cuidado de lidar com pessoas, com gente, com profissionais. Na teoria tudo muito bem planejado, mas na prática uma desordem. Ao invés de se sentir valorizado o servidor público se viu num contexto de total desvalorização, pois a crítica ferrenha em cima da administração burocrática atingiu diretamente o servidor.

Chanlat (2002) descreve perfeitamente as conseqüências que as mudanças administrativas provocaram no trabalho público: 
- Aumento da carga horária de trabalho: com a redução do quadro de pessoal e nova exigência de desempenho e produtividade, principalmente dos servidores que estão em contato direto com o cliente;

- Aumento da autonomia: maior responsabilidade do servidor frente ao seu trabalho, em contrapartida o servidor tem uma realidade de obediência à hierarquia - controle e poder;

- Reconhecimento: contexto de crítica interna (Governo) e externa (Imprensa/setor privado) com relação ao desempenho do servidor, herança da crítica à administração burocrática;

. Instabilidade no emprego: Contrato com prazo determinado e terceirização é um forte fator de enfraquecimento dos relacionamentos e insegurança no trabalho;

- Ameaça à ética do serviço público, que força o funcionário a assumir comportamentos impessoais, passe a ser guiada apenas pela ética dos negócios desaparecendo a "imparcialidade, o tratamento igualitário e o interesse geral" (CHANLAT, 2002, p.6).

Essas questões assinaladas por Chanlat (2002) mostram o quanto o servidor público foi atingido pelas mudanças da gestão e o aumento do desgaste e sofrimento no trabalho, principalmente no que diz respeito à falta de reconhecimento e pela desqualificação pública que a administração gerencial trouxe aos servidores públicos.

De acordo com Paes de Paula (2005), há uma incompatibilidade entre a lógica gerencialista e o interesse público. Na tentativa de adaptar e transferir os conhecimentos gerenciais desenvolvidos no setor privado para o setor público gerou algumas limitações, tais como:

- Formação de uma nova elite burocrática;

- Centralização do poder nas instâncias executivas;

- Inadequação da utilização das técnicas e práticas advindas do setor privado;

- (PAES DE PAULA, 2002, p.82).

$\mathrm{Na}$ visão da autora (De Paula, 2005) a concentração do processo decisório a um grupo pequeno de burocratas, a dificuldade de lidar com a complexidade dos sistemas administrativos e a dimensão sóciopolítica da gestão demonstram que o novo modelo de gestão não substituiu, de fato, o antigo, pois os controles de processo propostos passaram 
dos políticos para um pequeno círculo de tecnocratas. $\mathrm{O}$ discurso de que a reforma na administração é uma reforma democrática tornou-se questionável, pois não teve a participação popular devido à falta de preparo para lidar com essa realidade, uma vez que a orientação do setor privado advém de um mundo completamente diferente do setor público, o que decisivamente afetou o modo de trabalho e de vida do servidor público.

De acordo com Wood Jr. (2008), os cinco princípios básicos consolidaram e compuseram um imaginário organizacional na ideologia gerencialista são:

1. a crença inabalável na liberdade de mercado (o retorno da "mão invisível”);

2. a visão dos indivíduos como empreendedores de si mesmos;

3. o culto da excelência como meio para o progresso individual e coletivo;

4. a crença de que as tecnologias gerenciais são válidas para tudo;

5. forte orientação para resultados e obsessão por produtividade.

\subsubsection{Poder na Administração Gerencialista}

Gestão para Gaulejac (2007), “é um sistema de organização de poder, onde esta por trás de sua imagem de neutralidade uma evolução considerável de poder.

\footnotetext{
"Sob a aparência objetiva, operatória e pragmática, a gestão gerencialista é uma ideologia que traduz as atividades humanas em indicadores de desempenhos, e esses desempenhos em custos ou em benefícios. Indo buscar do lado das ciências exatas uma cientificidade que elas não puderam conquistar por si mesas, as ciências da gestão servem definitivamente, de suporte para o poder gerencialista." (GAULEJAC, 2007 ,P.36).
}

A gestão gerencialista constrói, segundo Gaulejac (2007), uma imagem do humano como um "recurso a serviço da empresa, contribuindo assim para a instrumentalização".

O resultado e lucro ou a morte: esta é a proposta única que a gestão baseada no capitalismo oferece aos seres humanos. "Ela destrói continuamente aquilo que produz pela necessidade de produzir outra coisa." Nesse contexto "os negócios" prosperam e a ética de resultados substitui a moral - respeito ao ser humano como humano e não como um mero instrumento para se alcançar os resultados. 
Na visão de Gaulejc (2007), essa dominação gerencialista modificou práticas tais como: adesão voluntária à sanção disciplinar, a mobilização à obrigatoriedade, a iniciativa à imposição, a gratificação à punição, tudo isso baseado em um sistema de valores que incentiva o engajamento individual e a busca por lucro como um ideal a ser seguido, fazendo com que o trabalho se torne o lugar da realização do sujeito em si.. A invasão do espaço e do tempo particular é executada progressivamente.

A obsessão pela rentabilidade financeira e a cultura da urgência, faz com que o poder gerencialista opere como um sistema de solicitação. Este comportamento flexível, adaptável, capaz de se desenvolver no tempo, em função do contexto, das flutuações do mercado, das descobertas tecnológicas, das estratégias da concorrência.

$\mathrm{Na}$ perspectiva de Gaulejac (2007) a organização nesse contexto, faz com que seu empregado caminhe cada vez mais para o sofrimento. Esse sofrimento advém da cultura do alto desempenho, do clima de competição generalizada, causando esgotamento profissional e estresse. Essa pressão ultrapassa a vida organizacional, e está presente também nas cidades, na política, na família, nas relações amorosas, na sexualidade e no próprio ego dos indivíduos, agora objetos do gerencialismo. São capitais gerenciados para a produtividade com índices de desempenho baseados em custo-benefício.

É irrefutável a necessidade de direcionar o serviço público para um atendimento com qualidade ao cidadão e à sociedade. Entretanto, este deve ser um processo com objetivos estratégicos alicerçados em valores éticos, comportamentais, ou seja, em uma cultura construída em outras bases, levando o servidor público a adotar uma conduta positiva, que possa minimizar os aspectos do sofrimento e aumentar a possibilidade de resultados,

Para Chanlat (2002), um fator importantíssimo foi esquecido pelos reformadores para que mudança administrativa desse certo: o sentimento de orgulho vivido, fator de motivação, de pertencer a uma categoria ímpar, que se define pelo serviço à sociedade. Instalou-se uma cultura organizacional baseada na competição e no individualismo, em alcançar metas e obter resultados com eficiência em detrimento a saúde mental, emocional e por que não dizer profissional do servidor público, trazendo-lhe uma vida de sofrimento, cheia de preocupações, frustrações, medos e angustias. Nesse contexto as organizações se adaptam a ideologia gerencialista e "lançam mão dos mais diversos mecanismos, tais como 
regras, normas e estrutura de cargos para alcançar um incremento da produtividade e da produção" (SIQUEIRA, 2006).

Segundo Freitas (2000), as organizações devem ser compreendidas dentro de um contexto sócio-histórico. A organização encontra-se num cenário político de mudanças sérias que impactam diretamente e indiretamente o individuo como um todo-social, familiar e profissional. Conforme Siqueira (2006):

\begin{abstract}
A capacidade das organizações em determinar como o individuo deve se comportar, dentro e fora de seus ambientes, tende a transformá-las em instituições centrais [...] a realidade do individuo passa a ser cada dia mais a realidade vivenciada pela empresa, em sua relação com atores externos, com clientes e concorrentes (SIQUEIRA, 2006, p.56).
\end{abstract}

As organizações com as mudanças administrativas desenvolveram "o poder organizacional, que de acordo com Pagés et al. (1987,p.98) “é exercido por meio de regras” , normas e crenças que são passadas nos vários campos e atinge diretamente o individuo.

Siqueira (2006) usa uma linguagem metafórica para exemplificar o jogo de poder na organização: diz que a organização se assemelha a uma arena. E desta forma quase um duelo entre as parte acontece o jogo constante do poder, "onde as partes nem sempre tem consciência dos interesses de desejos da outra parte" (SIQUEIRA, 2006, p.56).

Nesse contexto de uma administração gerencialista, num ambiente completamente recheado de promessas que não serão compridas, segundo o autor, (2006, p.15), a organização cria um mundo fantasioso de um sucesso que o leva a se sacrificar pela organização; o individuo acredita que se a empresa crescer ele cresce com ela e assim conseguirá atingir o "poder" e seus próprios desejos pessoais. Até mesmo a inovação tão estimulada pela administração está limitada às regras e normas da organização que ela mesma criou, exercendo assim uma forma de poder sobre o individuo (Siqueira, 2006).

Quem ocupa cargos gerenciais é bombardeado por essas regras, normas e política organizacional, que transformadas em cultura organizacional o sufoca de tal maneira que, ao mesmo tempo em que o seduz para o crescimento profissional, o leva a uma vida de sofrimento, repleto de angústias e frustrações de promessas nunca realizadas e cada vez mais longe de se realizarem. 
De acordo com Enriquez (2007) o poder tem seus efeitos ambíguos: desejo e repulsa, prazer e sofrimento. Ter, submeter-se, delegar, tomar o poder são preocupações cotidianas do ser humano, acrescenta o autor.

Analisando as relações subjetivas entre trabalhador e empresa, segundo Enriquez (2007), existem grandes contradições no mundo econômico e suas teorias. Por um lado há a exploração do capitalista em cima do operário, desvalorizando sua mão de obra com pagamentos baixos, tornando-o incapaz de reagir e, transformando-o em objeto, sem consciência, sem poder. Ao mesmo tempo, oferece serviços de auxilio social, passando uma imagem de cuidado e preocupação com os indivíduos que trabalham em suas organizações, e na realidade querem conservar sobre eles o domínio e o poder.

Pagés et al.(1987) aborda as contradições existentes numa vertente psicanalítica, onde a organização é vista como mãe protetora e acolhedora, que protege quando necessário e o gerente como pai severo, que cobra os resultados e desempenho nas tarefas. Segundo o autor existe todo um contexto de sedução construído em volta do individuo para mantê-lo sob controle, contexto este regado por regras e normas que definem sua participação e seu comportamento dentro da organização. Segundo a visão do autor Pagés et al. (1987), dentro do processo de controle organizacional o individuo se socializa e passa por uma doutrinação para seguir e atingir os interesses e objetivos da organização, sem ter abertura alguma para participação ou questionamentos.

Segundo Freitas (2006), o discurso organizacional é extremamente sedutor, buscando dar sentido à própria vida do individuo, onde ele somente realizará seus sonhos trabalhando na organização “x”. Nesse processo de sedução, continua Freitas (2000), as organizações “exploram vínculos psicológicos e afetivos nas suas relações com os indivíduos, especialmente no que diz respeito à adesão e à lealdade" (SIQUEIRA, 2006, p.11), pois se espera do trabalhador sua firmeza no comprometimento, perfeição na performance e cumplicidade na batalha ferrenha contra os concorrentes. E ainda na visão da autora:

"O indivíduo desenvolve pela empresa uma relação amorosa e devota ao seu nome, ao seu produto, ao seu projeto. Nessa relação existe uma gestão do afetivo, a concretização do poder que se faz amar. Mas nenhuma organização é capaz de amar, de ter sentimentos, de experimentar emoções, esperanças ou remorsos." (SIQUEIRA, 2006, p.11), 
De acordo com Freitas (2006), não se pode esquecer a natureza artificial e jurídica da organização, que a impossibilita ter qualquer sentimento humano. É o individuo que, seduzido pelo discurso organizacional, transfere para a empresa seus sentimentos e desejos. A reciprocidade nesse caso é ilusória e impossível. Daí as frustrações e decepções dentro das organizações.

Além da sedução, as organizações também utilizam outro artifício, segundo Siqueira (2006), que é a fascinação. É um outro tipo de controle ligado ao amor.

Com esses dois instrumentos sob seu poder, sedução e a fascinação, as organizações habilmente exercem seu domínio e impõem sua cultura, impedindo o trabalhador de expor sua opinião e castra-lhe o pensamento, tornando-o, aos poucos estéril e sem vigor.

Envolvido pelo discurso organizacional de uma empresa que "se vê como toda poderosa e onipotente" (Siqueira, 2006, p 54), o individuo é seduzido pelo fascínio do poder, da sensação de pertencer a um grupo poderoso ou a um órgão importante, a um mundo que o ajudará a realizar seus desejos.

Tendo como suporte a fundamentação teórica apresentada, que servirá como alicerce para a análise dos resultados, segue-se a exposição da metodologia empregada, que norteou toda a pesquisa. Os objetivos propostos foram de discutir o processo de modernização da administração pública e identificar a presença do gerencialismo em uma empresa pública, tendo como objeto de propagação para ascensão da ideologia gerencialista o treinamento gerencial.

Sendo assim, a análise dos resultados a seguir, busca verificar a presença do gerencialismo na relação da empresa com os gerentes, baseado nos treinamentos oferecidos, na cultura apresentada e no contexto organizacional presente nesta empresa pública. 


\section{METODOLOGIA}

O momento de construção metodológica para a pesquisa empírica apresenta-se como uma das principais inquietações de quem pesquisa, frente a um problema que deve ser analisado e compreendido criteriosamente. A escolha da metodologia a ser aplicada deve caracterizar-se pelo rigor científico nas observações dos fenômenos sociais.

Neste capítulo foram descritos o planejamento que foi executado na pesquisa empírica, assinalando: tipo de pesquisa, caracterização da organização, participantes da pesquisa, critérios de seleção dos participantes, instrumento de coleta de dados, os procedimentos para a coleta de dados e as análises a que foram submetidos os dados coletados.

\subsection{Tipos de Pesquisa}

De acordo com a taxionomia apresentada por Vergara (2000, p. 46-48), a classificação da pesquisa baseia-se em dois critérios básicos: quanto aos fins e quanto aos meios. A pesquisa aplicada é qualitativa e, no que diz respeito aos fins, exploratória e descritiva. Exploratória, porque, embora a empresa tenha mais de 40 anos de existência, não houve nenhuma investigação sobre os indícios ou ascensão do gerencialismo na organização. Descritiva porque teve como objetivo descrever as percepções, posições e idéias do corpo funcional responsável pela contratação e planejamento de treinamento gerencial.

Quanto aos meios a pesquisa foi bibliográfica, de campo e documental: bibliográfica porque para a fundamentação teórica foram realizadas pesquisas sobre os seguintes assuntos: Modernização do Estado, Gestão Pública, Gerencialismo, Ética no Setor público, Motivação no Trabalho e Discurso Organizacional. De campo, porque serão realizadas entrevistas individuais que, de acordo com Godoy (1995, p.62), devemos considerar todos os dados da realidade, pois são importantes e devem ser examinados. "O ambiente e as pessoas nele inseridas devem ser olhados holisticamente: não são reduzidos a variáreis, mas observados como um todo". De acordo com Lüdke e André (1986, p.28), o pesquisador deve começar como um espectador e gradualmente vai se tornando um participante. $\mathrm{O}$ 
conceito de entrevista do ponto de vista de Zanelli (2002, p. 33) é de uma conversa com um propósito definido. Nessa perspectiva, as entrevistas tiveram como principal objetivo identificar as práticas do gerencialismo no contexto da organização. Documental, porque foram realizadas investigações nos projetos do programa de treinamentos gerenciais, sítio com treinamento gerencial em EAD e outros documentos internos da organização, que de acordo com Vergara (2000, p 48) a pesquisa documental constitui uma investigação em documentos reservados pertencentes aos órgãos públicos ou privados de qualquer natureza: registros, anais, regulamentos, circulares, ofícios, memorandos, balancetes, comunicações informais, filmes, microfilmes, fotografias, disquetes, diários, cartas pessoais e outros.

\subsection{Características da Organização}

A pesquisa foi realizada numa empresa pública, em sua Sede, localizada em Brasília, Distrito Federal, trazendo consigo mudanças na estrutura organizacional, iniciando um processo de transformações na cultura da empresa.

A empresa pública em questão tem como finalidade prestar serviço de TIC para o Governo Federal. A estrutura da empresa é nacional, tendo representação nas principais capitais do país. Mas concentram em Brasília, na Sede, toda diretoria, superintendências e setores responsáveis pela gestão de pessoas. Por isso a pesquisa foi feita na Sede, no setor que planeja todo o programa gerencial para o corpo gerencial da empresa.

\subsection{Participantes}

Logo após a descrição da organização, mostramos o processo de seleção dos participantes da pesquisa, que teve como finalidade captar nos discursos dos envolvidos no programa de elaboração e execução dos treinamentos gerenciais, os indícios e a presença do gerencialismo na organização. Conforme Gaskell (2002) a compreensão dos mundos da vida dos entrevistados é a condição sine qua non da entrevista, pois deve estar em harmonia com as intenções do entrevistador. Como o número de entrevistados foi pequeno, o pesquisador teve que usar sua imaginação social científica para montar a seleção dos respondentes. (GASKELL, 2002, p.70). 
Foram entrevistados três profissionais que atuam na área de planejamento e contratação de consultorias para treinamentos gerenciais. Esses profissionais estão lotados em dois setores: um setor de consultoria gerencial, que trabalha diretamente com a coordenação de planejamento e execução dos treinamentos, gerências e contratação de consultorias com ensino à distância e no setor de planejamento e execução dos treinamentos gerenciais e contratação de consultorias com ensino presencial.

Perfil dos Entrevistados - Quadro Sintético

\begin{tabular}{|c|l|l|l|l|}
\hline Entrevistado & Cargo & Função & Formação & Sexo \\
\hline A & Analista & Analista & Superior & Masculino \\
\hline B & Analista & Analista & Superior & Feminino \\
\hline C & Técnico & Gerente & Superior & Feminino \\
\hline
\end{tabular}

Foi realizada também uma pesquisa documental no portal de cursos gerenciais, exclusivos aos gerentes e oferecido por uma empresa privada contratada pela organização.

\subsection{Instrumento}

Conforme Lüdke e André (1986, p.34), “a entrevista representa um dos instrumentos básicos para a coleta de dados, pois ela traz um grande beneficio sobre outras técnicas e permite a captação imediata e corrente da informação desejada". Ainda de acordo com Lüdke e André, permite também correções, esclarecimentos e adaptações que a tornam eficiente e eficaz na obtenção das informações. Baseado nos conceitos de Lüdke e André existem três tipos de entrevistas: a estruturada, que tem um roteiro a ser seguido, a nãoestruturada que tem liberdade de percurso e entre esses dois pontos completamente diferentes está a semi-estruturada, que se desenrola a partir de um esquema básico, porém não aplicado rigidamente, permitindo adaptações do entrevistador (LÜDKE, 1986, p.34).

Tendo em vista o objetivo desse trabalho, decidiu-se por conduzir entrevistas semiestruturada, por serem mais flexíveis e, apesar de seguirem um roteiro de perguntas não há impedimento para criação de novas perguntas e considerações sobre o tema da pesquisa, ao longo do desenvolvimento da entrevista. 
Lüdke e André afirmam que o entrevistador precisa está atento não apenas ao roteiro preestabelecido, mas "há toda uma gama de gestos, expressões, entonações, sinais nãoverbais, hesitações, alterações de ritmo, enfim toda uma comunicação não verbal cuja captação é muito importante para a compreensão e a validação que foi efetivamente dito" (LÜDKE, 1986, p.36). É muito importante que o entrevistado esteja bem informado sobre os objetivos da entrevista e de que as informações fornecidas serão utilizadas exclusivamente para fins de pesquisa" (LÜDKE, 1986, p.37).

Tendo como base esses conceitos as entrevistas foram conduzidas após apresentação aos participantes do conceito de gerencialismo adotado na literatura. Conforme Pasquali (1999), os conceitos devem ser de forma clara e objetiva, sempre com base na literatura. Seguindo esta linha de raciocínio, torna-se relevante citar novamente os conceitos da pesquisa: gerencialismo: O gerencialismo, segundo Chanlat (2002, p.9), “é um sistema de descrição, explicação e interpretação do mundo a partir das categorias da gestão privada" e crítica às organizações burocráticas, a valorização da cultura do management e a conversão de técnicas e práticas administrativas em modismo gerenciais (PAES DE PAULA, 2002, p.54).

Gaskell chama o roteiro de tópicos guias e, para ele, é a parte vital do processo de pesquisa e necessita de atenção detalhada (GASKELL, 2002, p. 64). Por isso, a fim de ilustrar como será o processo de coleta de dados, os tópicos guias foram elaborados para direcionar as questões na entrevista.

As informações para se identificar a presença do gerencialismo na empresa pública federal foram coletas por meio de entrevistas individuais semi-estruturas, a partir de um roteiro organizado para verificar quais eram as expectativas da organização sobre os treinamentos gerenciais, quais as expectativas com relação ao comportamento do gerente, as competências necessárias para um "bom” gerente, planejamento e ferramentas de gestão.

O roteiro de entrevista foi planejado de acordo com os seguintes temas que nortearam as questões que foram colocadas aos entrevistados:

1. Treinamento gerencial: onde ser quer chegar; 
2. A influência do treinamento gerencial no trabalho;

3. A utilização de novas tecnologias e sistemas de informação no desempenho gerencial;

4. Competências gerenciais;

5. As relações de poder;

6. Discurso organizacional.

Para pesquisa documental foi considerado todo referencial teórico e em especial as conseqüências do gerencialismo citadas por Chanlat (2002) em seu discurso sobre gerencialismo e a ética do bem comum.

\subsection{Procedimentos e Coleta de Dados}

Foi realizada pesquisa qualitativa - entrevistas individuais, com três funcionários responsáveis pelo programa de treinamento gerencial na instituição. O intuito foi de fazer um levantamento de dados sobre as contratações de consultorias de empresas privadas para realizarem treinamentos gerenciais no setor público, e perceber o discurso gerencialista na instituição.

A efetivação da pesquisa junto à instituição foi precedida de autorização prévia e foi preservada a identidade da instituição.

Para a realização das entrevistas foi mantido contato prévio com os responsáveis para agendamento da data, horário e local das entrevistas. A coleta dos dados deu-se pelo registro pessoal da pesquisadora tendo como meio um gravador. Logo após a transcrição da entrevista, a gravação foi apagada, conforme acordado com todos os entrevistados.

Durante a entrevista utilizou-se a técnica da associação livre, que segundo Bauer e Gaskell (2002), ajuda o pesquisador conseguir mais informações sobre o tema em questão. O objetivo é levar o entrevistado a relatar sobre suas atividades no trabalho, a forma de planejamento e programação dos treinamentos, critérios para contratação de consultoria e para temas dos treinamentos e expectativas pós-treinamento. 


\subsection{Análise dos Dados}

Primeiramente, será realizada uma análise de conteúdo dos dados coletados nas entrevistas, para auxiliar na estruturação dos objetivos da pesquisa, e do conteúdo obtido no sítio da empresa responsável pelos cursos gerenciais à distância. Foram categorizados conforme a apresentação do sítio e tendo como apoio a literatura estudada e que foi baseada toda fundamentação teórica .

Além da análise de conteúdo, optou-se também pela análise do discurso do material adquirido por meio da coleta de dados. A análise do discurso de acordo com wikipedia "é uma prática e um campo da lingüística e da comunicação especializado em analisar construções ideológicas presentes em um texto. De uma forma reflexiva põe em questões práticas realizadas em diversos contextos. Ainda, conforme wikipedia:

\footnotetext{
"Discurso é a prática social de produção de textos. Isto significa que todo discurso é uma construção social, não individual, e que só pode ser analisado considerando seu contexto histórico-social, suas condições de produção; significa ainda que o discurso reflete uma visão de mundo determinada, necessariamente, vinculada à do(s) seu(s) autor(es) e à sociedade em que vive(m). Texto, por sua vez, é o produto da atividade discursiva, o objeto empírico de análise do discurso; é a construção sobre a qual se debruça o analista para buscar, em sua superfície, as marcas que guiam a investigação científica. É necessário porém salientar, que o objeto da Análise do Discurso é o Discurso".
}

Seguindo o mesmo pensamento, Siqueira (2006), reforça que, torna-se indispensável conhecer o contexto sócio-histórico em que se encontra o texto e não somente isso, mas e o que está explícito e implícito no texto, isto é, o que foi dito e o não dito, o oculto. A ideologia subjacente no discurso deve ser analisada e compreendida, pois "as palavras contêm um alto grau de contornos ideológicos e de sentidos que não estamos acostumados a perceber de maneira rápida e contínua” (SIQUEIRA, 2006p. 101).

O discurso desempenha um papel primordial nas relações sociais; ele coopera diretamente tanto para o desenvolvimento como para as mudanças nas sociedades (SIQUEIRA, 2006).

Dando seqüência à pesquisa, após a coleta dos dados e leituras sucessivas de todo material, procurou-se a identificação dos temas de acordo com o arcabouço teórico em que 
está toda a pesquisa, para facilitar a conexão com os objetivos propostos. Foram criadas as categorias que de acordo com Zanelli (2002, p.84):

Organizar e interpretar dados qualitativos é um processo de análise sistemática, em busca de uma descrição coerente. A organização em categorias facilita e permite atribuir significados, ou interpretar a realidade pesquisada. A análise (organizar e interpretar) é também um processo recorrente de aprendizagem para chegar à compreensão do fenômeno.

As categorias definidas no início foram aprimoradas e ampliadas, passaram por novos crivos de julgamentos quanto a sua relevância e delimitações. No capítulo seguinte são apresentados e discutidos os resultados das análise de conteúdo e do discurso dos dados obtidos na pesquisa 


\section{RESULTADOS E DISCUSSÃO DOS RESULTADOS}

Esta parte do trabalho contém os resultados obtidos a partir da análise de conteúdo do sítio de uma empresa privada que fornece treinamentos exclusivos aos gerentes da empresa pública federal que está sendo pesquisada.

Contém, também, a análise do discurso baseada nas entrevistas realizadas com os responsáveis pelo programa de treinamento da empresa e corroboram os resultados obtidos e as percepções do discurso organizacional na empresa. Os resultados foram discutidos à luz da literatura revisada.

Para uma melhor compreensão e visualização dos temas, optou-se por apresentar essa seção separada em itens. Os itens estão de acordo com a didática apresentada no sítio:

1. Competências

2. Carreira, Produtividade e Desempenho

3. Gestão Pública

Baseada na divisão do sítio estabeleceu-se, então, três categorias, assim definidas e descritas:

\subsection{Forte Orientação para Resultados e Obsessão por Produtividade}

\section{Descrição: Competências}

Os cursos apresentados nesta categoria são cursos direcionados para o desenvolvimento de competências básicas para um bom gerenciamento na organização e é dividido em oito competências:

> Atuação Estratégica - Capacidade de compreender cenários, perceber tendências, identificar oportunidades e ameaças, fraquezas e forças e desenvolver ações com visão de curto, médio e longo prazo, para o êxito das estratégias e planos corporativos;

> Comunicação - Capacidade de comunicar-se de forma clara e objetiva, demonstrando segurança ao se expressar e obtendo a confiança das pessoas. Busca uma linguagem e meios de comunicação adequados com a equipe, clientes e demais unidades, procurando ouvir e compreender as pessoas; 
> Gerenciamento do desempenho das pessoas - Capacidade de direcionar os esforços de pessoas e grupos para o alcance dos objetivos de sua área em alinhamento com o negócio da unidade e as estratégias da Empresa. Incentiva o aprendizado, facilita o desenvolvimento de pessoas e equipes e promove um clima motivador e harmônico na área;

> Gestão centrada no cliente - Capacidade de identificar e entender as necessidades e expectativas dos clientes, antecipar soluções, promover satisfação e conquistar sua fidelidade, visando novas oportunidades para a unidade e a Empresa;

> Inovação e criatividade - Capacidade de apresentar algo novo ou reelaborar e aperfeiçoar produtos, serviços, processos ou procedimentos já existentes com impacto relevante para a unidade. Propicia um ambiente de trabalho favorável para a expressão da criatividade dos subordinados, com vistas à inovação da organização;

> Negociação - Capacidade de influenciar, persuadir e obter consenso no processo de negociação, com objetivo de atingir resultados satisfatórios para todas as partes envolvidas sem perder o foco nos objetivos da negociação;

> Orientação para resultados - Capacidade de estruturar e estabelecer estratégias, metas e ações de forma a atingir os resultados esperados, dentro dos prazos e padrões estabelecidos. Define o seu papel e os dos subordinados, estabelecendo mecanismos de acompanhamento e controle de resultados;

> Responsabilidade pública e social - Capacidade de promover valores, práticas e comportamentos morais, éticos e socialmente responsáveis, estimulando o exercício da cidadania de forma a contribuir para o desenvolvimento e o aprimoramento das pessoas e para a formação de uma sociedade sustentável e solidária.

\section{Discussão}

Verificou-se que as competências a serem desenvolvidas segundo os cursos direcionam para o discurso gerencialista, apresentando uma forte orientação para resultados e obsessão por produtividade. A fala do entrevistado C: "Os gerentes têm que estar alinhados ao planejamento da empresa e buscar se enquadrar no que a empresa espera dele: eficiência e produção" e, também, a do o entrevistado B: "espera-se que os gerentes desenvolvam as competências necessárias para poder gerenciar e produzir o esperado pela empresa" ratificam todo o discurso na organização, que tem como foco produtividade e resultados. 
Os trechos aqui transcritos revelam o exercício do poder, onde os gerentes têm que se "enquadrar no que a empresa espera dele" fazendo assim um esforço sub-humano para manter seu cargo na empresa. Tendo uma vida de pressões que refletem infelizmente em todas as áreas de sua vida.

O objetivo dos cursos é de desenvolver competências necessárias para que o trabalhador produza cada vez mais, trazendo os resultados esperados e fazendo de sua vida uma extensão da empresa.

Negociação, resultados e produtividade são palavras-chaves na administração gerencialista, e estão presentes em todos os cursos.

$\mathrm{Na}$ gestão gerencialista o gerente tem que se adaptar às necessidades produtivas e financeiras da empresa, numa exigência de mão única.

Percebe-se atualmente as organizações estão mais inquietas com relação aos seus recursos humanos simplesmente porque querem o aumento da produtividade e alcançar seus objetivos - rentabilidade, baseados num capitalismo selvagem, onde o ser humano tornou-se um instrumento de lucratividade (SIQUEIRA,2006).

Uma das competências a serem desenvolvidas é a de ter responsabilidade política e social, as empresas querem passar uma imagem de "preocupada" com política, cidade e o cidadão, mas querem mesmo é falar de suas marcas e de "seus interesses, dos quais não perder é um dos mais fortes". "Respeitar a ecologia, se não dá dinheiro, pode evitar prejuízo - prejuízo com a imagem da empresa e os riscos de ser boicotada" (FREITAS,2000,p10-11). Projetos culturais e ecológicos além de serem um excelente marketing, traz consigo descontos e portas abertas para o mercado e o cliente em geral. - uma forte visão da gestão gerencialista.

Conforme entrevistado A: "A idéia é que o gerente atinja os resultados esperados pela empresa", portanto, com o desenvolvimento dessas competências a vida do empregado deve girar em torno dos objetivos da empresa. Um convite sutil para o individuo viver em função de alcançar as metas da organização.

No curso Gerenciando o Desempenho das Pessoas, percebe-se o controle da organização sobre o individuo para o alcance de seus objetivos. A sinopse do curso traz o seguinte: "Capacidade de direcionar os esforços de pessoas e grupos para o alcance dos objetivos de sua área em alinhamento com o negócio da unidade e as estratégias da Empresa. Incentiva o aprendizado, facilita o desenvolvimento de pessoas e equipes e promove um clima 
motivador e harmônico na área”. Observa-se que há um incentivo para o desenvolvimento de um clima motivador na empresa onde o desempenho do empregado é controlado e medido apenas com parâmetros de produtividade e rentabilidade. O recurso humano é tratado como mais um recurso.

\subsection{Cultura do Management e Comprometimento Afetivo}

\section{Descrição: Carreira, Produtividade e Desempenho}

Os cursos apresentados nessa categoria são cursos direcionados para o desenvolvimento profissional e gerencial com orientações para ascensão na organização e é dividido em quatro temas:

> Alavancando sua carreira - Aprender a gerenciar a dinâmica que existe por trás do poder e da influência; aprender como ajustar o seu estilo gerencial às necessidades de desempenho da sua equipe ou do seu departamento; formar equipes eficazes e de bom desempenho; lidar eficazmente com as tensões e emoções que surgem quando se torna um gerente.

$>$ Aumentando sua produtividade - um guia prático de como se comunicar por escrito de maneira mais clara e eficaz; como planejar e conduzir reuniões; apresenta ferramentas práticas para avaliar a designação de uma tarefa a uma pessoa, selecionar a pessoa certa e combinar suas habilidades com os desafios do trabalho, e apoiá-la durante todo o processo. Inclui estratégias de como comunicar a designação, monitorar o progresso e lidar com a inversão de responsabilidades; apresenta estratégias eficazes para gerenciar o estresse, identificar o seu próprio nível de estresse e os tipos de reações de uma pessoa estressada. Soluções de longo prazo, explorando as causas subjacentes do estresse, com sugestões de como alterar as situações que o causam. Soluções de curto prazo, de como lidar com problemas imediatos. Onde se encontram inúmeros conselhos práticos, ferramentas para avaliação do estresse, checklists que ajudará a dividir grandes problemas, geradores de estresse, em porções mais administráveis, e dicas de como lidar com situações específicas; apresenta técnicas e estratégias de gestão eficaz do tempo; um guia passo a passo de como preparar, conduzir e fazer o follow-up da avaliação de desempenho. Inclui diretrizes sobre documentação apropriada e como lidar com situações desafiadoras, bem como 
passos específicos a serem usados antes, durante e depois de avaliações de desempenho eficazes.

> Definindo sua marca pessoal - um guia prático de como identificar seus reais interesses profissionais, suas melhores habilidades e seus valores de recompensa pelo trabalho. Como usar essas informações para decidir que passo é o mais indicado para o seu caso específico e como estabelecer alvos de carreira encorajadores. Também vai receber conselhos práticos de como se beneficiar de consultores de carreira, mentores, trabalho em rede, entrevistas informativas e revisões de desenvolvimento profissional - e como ajudar outros a gerenciar suas carreiras.

> Melhorando a performance de sua equipe - Para dar responsabilidade e poder a seus funcionários terá de elaborar uma visão compartilhada sobre o que se deseja alcançar. Em seguida, demonstrar como eles podem tornar isso uma realidade. Assim que as pessoas conseguem entender o que se espera delas, elas se sentem responsáveis e capazes.

\section{Discussão}

Percebe-se nitidamente nessa categoria que nos cursos oferecidos existem crenças gerencialistas, que são passadas como verdades únicas e recebidas sem questionamentos ou observações. Os gerentes são bombardeados por um vocabulário cheio de siglas e chavões, idéias mirabolantes mas que na prática não são aplicáveis no setor público. Há a instrução para se adotar as literaturas de negócio e gestão com um fervor religioso, como um guia espiritual para enfrentar as dificuldades e oportunidades da vida corporativa.

O discurso gerencialista na empresa reforça a crença na visão do individuo como empreendedor de si mesmo, e como diz Wood Jr.:

\footnotetext{
“Alguns gestores contemporâneos apresentam comportamento maníaco-depressivo: seu humor oscila entre momentos marcados por temores e preocupações com a própria sobrevivência e momentos de euforia, marcados por sonhos de grandeza e pela elaboração de estratégias de ascensão. Muitos leitores adotam a literatura de negócios e gestão com fervor religioso. Tratam-na como guia espiritual para enfrentar chagas e oportunidades da vida corporativa. "( WOOD JR. 2008,p.1)

O perfil traçado para o funcionalismo público nos cursos revela a contradição e a
} incompatibilidade dos comportamentos entre si, como: ser competitivo e ao mesmo tempo cooperativo, individualista e capaz de trabalhar em equipe, tomar iniciativa e conformar-se às regras difundidas do modelo de homem produtivo das organizações, onde os critérios que 
incluem são os mesmo que excluem e trouxeram efeitos colaterais danosos ao setor público. A crise de identidade vivida pelo funcionalismo permite a ampliação do papel das organizações na vida do individuo (Freitas,2000).

Neste contexto, as organizações investem em qualquer tipo de treinamento gerencial para tornar seus gerentes flexíveis, com as práticas mais inusitadas, visando fazê-los indivíduos mais adaptáveis no menor espaço de tempo. Não há uma avaliação se os treinamentos são adequados para uma organização pública, se as ações propostas e os comportamentos exigidos aos gerentes são apropriados à gestão pública e quais as conseqüências desses treinamentos para a organização e para a vida de seus empregados (FREITAS, 2000).

Há o estímulo ao individualismo sem medida, que torna o gerente uma celebridade e a se ver como marcas de produtos. Vale a pena citar Wood Jr. (2008, p. 89), “a paixão pela carreira (rápida) substituiu a paixão pelo trabalho (sério)" e, complementando com Freitas, "Não se ganha pelo que se vale, mas se vale pelo que se ganha". (FREITAS,2000, p.8).

Comprometimento é a palavra-chave no discurso organizacional movido pela gestão gerencialista, onde o individuo é envolvido e seduzido pelas promessas de sucesso da empresa. Nesse processo de sedução, continua Freitas (2000), as organizações "exploram vínculos psicológicos e afetivos nas suas relações com os indivíduos, especialmente no que diz respeito à adesão e à lealdade" (SIQUEIRA, 2006, p.11),

$\mathrm{Na}$ visão de Siqueira (2006,p.139), “a lógica do comprometimento organizacional pressupõe a fascinação, a sedução e a esperada servidão voluntária de seus funcionários”. Atualmente nas organizações "uma das principais funções da área de gestão de pessoas é a de auxiliar na criação do ambiente de envolvimento do empregado para com os objetivos da organização, passando a ter um comprometimento afetivo e instrumental com a organização".

O discurso organizacional dos entrevistados corrobora a teoria de Siqueira, pois o entrevistado $\mathrm{C}$ declarou que uma das competências básicas para o gerente é o "comprometimento". Assim o treinamento tem papel fundamental, pois por meio de cursos de "vivências participativas" ou tudo aquilo que estiver na moda, o individuo mergulha no universo da empresa.

Os entrevistados foram seduzidos pelo discurso organizacional cheio de promessas de sucesso. A servidão voluntária é claramente perceptível na fala do entrevistado C: "Comprometimento pra mim é a palavra-chave para o sucesso do gerente" e "a empresa está disponibilizando para os empregados acessos aos treinamentos, e-mail e outros ambientes em 
casa, para ajudá-lo em seu trabalho. Ainda bem! Só assim consigo adiantar meu trabalho...”, tendo como conseqüência o aumento da carga horária de trabalho. Essa cultura de efíciência, produtividade e urgência de solicitações faz com que os gerentes não percam a posse do seu tempo pessoal, mas o tempo de trabalho passa a invadir esse tempo como uma conseqüência lógica do seu desejo de sair-se bem e ter sucesso.

A organização está sempre analisando a possibilidades de alcançar seus objetivos e a melhor forma de aumentar seus retornos (SIQUEIRA,2006), promete dividir com o empregado o seu sucesso e no discurso estão as promessas que não serão cumpridas, um jogo de sedução que envolve o individuo prometendo torná-lo num superexecutivo (SIQUEIRA,2006) e,"ao mesmo tempo, a empresa é um lugar onde o individuo pode realizar seus sonhos e diminuir suas angustias" (SIQUEIRA,2006,p.145).

Segundo Paes de Paula (2005, p.53), o movimento reinventando o governo "está diretamente relacionado com a emergência da indústria do management: escolas de administração, as empresas de consultorias, gurus empresariais e a mídia de negócios" e é o que apresenta os cursos do sítio analisado.

Os cursos oferecidos para os gerentes da empresa pública federal propõem melhores práticas - essas são as palavras do sítio -, mas surge a pergunta: práticas que deram certo para quem? Para a empresa com certeza! Pergunta-se a que custo? Custo de vidas, de recursos humanos que abdicaram de suas vidas para viver a "vida da empresa". O treinamento interessa a quem está no poder e auxilia no discurso organizacional, transmitindo toda a sua ideologia, como foi relatado pelo entrevistado B: "Anteriormente a linha dos treinamentos era comportamental, mais focada no empregado, agora os treinamentos estão mais focados em técnicas e ferramentas mais adequadas para desenvolvimento dos gerentes”. Observa-se a mudança de visão atualmente na empresa, pois conforme relata $\mathrm{o}$ entrevistado $\mathrm{B}$, antigamente a linha dos treinamentos era comportamental. Houve uma alteração nos rumos dos treinamentos na empresa. A vertente comportamental foi trocada pela vertente gerencial onde o que importa são as ferramentas e as técnicas que os gerentes usarão para produzir melhor. Percebe-se uma total falta de preocupação com o individuo. A crença de que as tecnologias gerenciais são válidas para tudo como se as ferramentas fossem operar sozinhas. Considera-se mais as 
ferramentas que o trabalhador e suas necessidades. Nessa fala está embutido todo o discurso gerencialista e a visão do recurso humano como instrumento de rentabilidade.

\section{3 Ética de Negócios e Crença Excessiva na Tecnologia e Ferramentas de Gestão}

\section{Descrição: Gestão Pública}

São apresentados sete cursos com dicas e ferramentas para uma gestão eficiente e que estão resumidos nos textos abaixo devido redundância de abordagens:

$>$ A chave para se alcançar um equilíbrio possível na vida profissional é estabelecer expectativas razoáveis, de acordo com suas circunstâncias, e estar ciente de que algumas vezes terá de abrir mão de algumas coisas que poderão ser compensadas no futuro.

> Mesmo em uma organização comprometida com a flexibilidade, muitas vezes é possível que algumas formas entrincheiradas de comportamento e de burocracia resistam fortemente às mudanças. Vencê-las exige muita persistência.

$>$ O setor público pode algumas vezes perder de vista sua necessidade de servir ao público e, em vez disso, incorporar sistemas pesados, ensimesmados, herméticos e inertes. De modo que os líderes precisam ser mais receptivos às mudanças no mundo exterior e ser mais transparentes, adotando um modelo de liderança voltado para valores e convicções.

As lições essenciais apresentam lições de vida - com foco empresarial - dos líderes das empresas mais influentes do mundo. Histórias reais que retratam anos de experiência prática em negócios, liderança e gestão. Verdadeiros insights para grandes desafios.

> Harvard ManageMentor é um programa de desenvolvimento de lideranças voltado para gestores que não têm tempo a perder. Permite ao usuário acessar exatamente o conteúdo que precisa, no momento mais adequado às suas necessidades. Apresenta ferramentas 
de trabalho e planejamento de uso diário e de fácil aplicação, de forma interativa, atual e com simulações de experiências cotidianas.

\section{Discussão:}

A "nova administração pública" origina-se na teoria da escolha pública e no neoliberalismo, que defendiam a "transferência de princípios da economia para o campo da política" (PAES DE PAULA, 2005, p.33) e o individuo como um simples instrumento utilitário para alcançar as metas e interações econômicas, sociais e políticas (PAES DE PAULA, 2005). Tendo por base os exemplos dos governos de Margaret Thatcher, na Inglaterra e de Ronald Reagan, nos Estados Unidos da América, em fins da década de 70 e começo dos anos 1980 (PAULA, 2005a, p.36).

Cabe ressaltar que uma parte dos autores dos cursos pertenceu ao setor público dos Estados Unidos e Inglaterra na década de 80 - países e anos que foram o berço da administração gerencial, que reforçava a supremacia da eficiência do mercado em relação ao Estado e, conseqüentemente, a crítica atroz à burocracia da administração pública. Outra parte dos autores são diretores e altos executivos de empresas privadas e multinacionais que passam em seus cursos toda a cultura organizacional de suas empresas e, mais que isso, passam suas ideologias e ética de negócios do setor privado como verdades únicas a serem seguidas.

Confirma-se que atualmente a organização pública é alvo das interferências diretas da empresa privada, uma vez que esta foi contratada para realizar treinamentos para gerentes. Essas influenciam fortemente a cultura da organização, com conceitos e práticas do setor privado. Essas práticas muitas vezes não se aplicam ao setor público pela própria diferença da natureza do trabalho.

O item Gestão Pública do sitio transmite a crença de que as tecnologias gerenciais são válidas para tudo, por suas qualidades e por seus poderes mágicos; são capazes de garantir os melhores resultados para as empresas. Na fala do entrevistado $C$, percebe-se claramente a crença nas tecnologias gerenciais que, por suas qualidades, são capazes de garantir os melhores resultados para as empresas: "Os cursos, mesmo sendo de uma empresa privada, se adequam perfeitamente à empresa pública, porque o que interessa são as técnicas e 
ferramentas para auxiliar o gerente na sua função". Assimila-se não somente as técnicas e o conhecimento das ferramentas, mas a ideologia que está subjacente a elas.

A gestão gerencialista instalada na empresa com uma imagem de pragmatismo, traz consigo a ideologia de transformar as atividades humanas em indicadores de desempenhos, e esses desempenhos em produtividade e lucro para a empresa. Além de exercer através das ferramentas de gestão o poder e o controle sobre as atividades do empregados.

A fala em todos os cursos é contra a burocracia do setor público e a disseminação da palavra chave na administração gerencial: flexibilidade. Na perspectiva de Freitas (2000) ser flexível tornou-se o grande sonho das empresas: pede-se dos gerentes serem flexíveis e renovarem sempre, trazendo-lhes exaustão e uma corrida frenética para ser chegar a um lugar que a cada dia se renova.

Flexibilidade que conforme "quando excessiva, não constrói nada, não consolida nada, não gera nada durável, não referencia nada, não garante nem a própria sobrevivência. já que não armazena nenhuma memória capaz de orientar uma tomada de decisão imprevista". (FREITAS,2000, p.12),

As ferramentas de gestão e a ética dos negócios norteada na competição acirrada e no capitalismo selvagem estão claramente presentes nos cursos oferecidos para os gerentes da empresa publica federal.

Segue abaixo tabela I e II comparativa com os elementos da Fundamentação Teórica e os elementos da Pesquisa de Campo e Documental, buscou-se complementar e criar uma sintonia com a descrição e a discussão das categorias:

\section{Tabela I - Elementos da Fundamentação Teórica e da Pesquisa de Campo}

\begin{tabular}{|l|l|}
\hline Elementos da Fundamentação Teórica & \multicolumn{1}{|c|}{ Elementos da Pesquisa de Campo } \\
\hline Obsessão por Produtividade & $\begin{array}{l}\text { Entrevistado C } \\
\text { "Os gerentes têm que estar alinhados ao } \\
\text { planejamento da empresa e buscar se } \\
\text { enquadrar no que a empresa espera dele: } \\
\\
\text { eficiência e produção." } \\
\\
\text { Entrevistado B } \\
\text { "Que desenvolva as competências } \\
\text { necessárias para poder gerenciar e produzir } \\
\\
\text { o esperado pela empresa. } \\
\text { Entrevistado A }\end{array}$ \\
\hline
\end{tabular}




\begin{tabular}{|c|c|}
\hline & $\begin{array}{l}\text { "A idéia é que o gerente atinja os resultados } \\
\text { esperados pela empresa." } \\
\text { Entrevistado B } \\
\text { "O foco dos treinamentos mudou, agora } \\
\text { temos que preparar gestores públicos e não } \\
\text { gerentes." }\end{array}$ \\
\hline $\begin{array}{l}\text { Crença excessiva na tecnologia e } \\
\text { ferramentas de gestão }\end{array}$ & $\begin{array}{l}\text { Entrevistado B } \\
\text { "Anteriormente a linha dos treinamentos era } \\
\text { comportamental, mas focada no empregado, } \\
\text { agora os treinamentos estão mais focados } \\
\text { em técnicas e ferramentas mais adequadas } \\
\text { ao desenvolvimento dos gerentes." } \\
\text { Entrevistado C } \\
\text { "Os cursos, mesmo sendo de uma empresa } \\
\text { privada se adequam perfeitamente à empresa } \\
\text { pública, porque o que interessa são as } \\
\text { técnicas e ferramentas para auxiliar o } \\
\text { gerente na sua função" }\end{array}$ \\
\hline Comprometimento afetivo & $\begin{array}{l}\text { Entrevistado C } \\
\text { "Comprometimento pra mim é a palavra } \\
\text { chave para o sucesso do gerente". } \\
\text { Entrevistado C } \\
\text { "A empresa está disponibilizando para os } \\
\text { empregados acessos aos treinamentos, e- } \\
\text { mail e outros ambientes em casa, para } \\
\text { ajudá-lo em seu trabalho. Ainda bem, só } \\
\text { assim consigo adiantar meu trabalho." }\end{array}$ \\
\hline
\end{tabular}

Tabela II - Elementos da Fundamentação Teórica e da Pesquisa Documental

\begin{tabular}{|l|l|}
\hline \multicolumn{1}{|c|}{ Elementos da Fundamentação Teórica } & \multicolumn{1}{c|}{ Elementos da Pesquisa Documental } \\
\hline Forte orientação para resultados & $\begin{array}{l}\text { Aumentando sua produtividade } \\
\text { Melhorando a performance de sua equipe } \\
\text { Orientação para resultados } \\
\text { Gerenciamento do desempenho das pessoas }\end{array}$ \\
\hline $\begin{array}{l}\text { Empreendedorismo - Cultura do } \\
\text { management }\end{array}$ & $\begin{array}{l}\text { Alavancando sua carreira } \\
\text { Definindo sua marca pessoal }\end{array}$ \\
\hline Ética dos negócios & $\begin{array}{l}\text { Negociação } \\
\text { Gestão centrada no cliente }\end{array}$ \\
\hline
\end{tabular}




\section{CONSIDERAÇÕES FINAIS}

Acima temos as descrições gerais dos temas dos cursos oferecidos a uma empresa pública, na categoria de $\mathrm{EAD}$, para o desenvolvimento gerencial e descrição das entrevistas de empregados que trabalham diretamente com treinamentos na organização. Percebe-se a utilização dos treinamentos como recurso da organização para internalizar seus objetivos que, de acordo com um dos entrevistados, "os cursos estão alinhados com as metas da empresa" servindo assim como instrumento de disseminação do discurso organizacional.

Para o cumprimento dos objetivos organizacionais, uma peça importante dentro desse processo é o gerente. De acordo com Davel e Melo (2005, p.37) “os gerentes favorecem a execução de um trabalho em quantidade e qualidade suficientes para a manutenção da cooperação e a garantia da reprodução das relações sociais". O gerente em sua função exerce ao mesmo tempo o poder e mediação de interesses.

$\mathrm{Na}$ reforma do Estado, onde a administração burocrática foi substituída pela administração gerencial, Bresser Pereira (1999), diz que o administrador burocrata precisa se transformar em gerente. Procurando ser o máximo eficiente, a preocupação é de definir políticas e ações administrativas que sejam satisfatórias, claras e transparentes e que busquem garantir que o interesse coletivo na produção de bens públicos pelo Estado seja minimamente atendido (BRESSER PEREIRA, 1999). Segundo Davel e Melo (2005) o gerente deve ser o "tomador de decisões, o empreendedor, orientado por resultados e pelo mercado, pragmático e estratégico, buscando sempre os melhores interesses de eficiência e eficácia da organização.”

Baseado numa gestão flexível, o Plano Diretor da Reforma do Estado estabeleceu um novo modelo de Administração voltado para o cidadão-cliente e a busca de resultados. Como diz Bresser Pereira (1999), enquanto a administração pública burocrática se aplica em realizar processos, em definir procedimentos para contratação de pessoal e para a compra de bens e serviços a administração pública gerencial direciona para resultados.

Para Freitas (2000) o conceito de flexibilidade se encaixa perfeitamente tanto no contexto organizacional como para os indivíduos, principalmente para aqueles que estão no topo da pirâmide organizacional. 
Determinados passos da administração gerencial proporcionou bons resultados e trouxeram melhorias em alguns aspectos da administração pública. Mas, sem dúvida nenhuma, causou e continua causando também malefícios à vida profissional e porque não dizer na vida particular do individuo como: medos, incertezas e angústias - sofrimentos vividos nas organizações. Tudo isso devido à lógica empresarial aplicada indistintamente e com a mesma roupagem do setor privado em todos os segmentos da administração pública (CHANLAT, 2002).

Tendo como objetivo principal o de identificar e analisar a presença e ascensão do gerencialismo no setor público, investigando o fenômeno em uma empresa pública federal, a pergunta que norteou a pesquisa para que o objetivo geral fosse alcançado foi: Quais eram os indícios da presença e ascensão do gerencialismo em uma empresa pública?

Desenvolveu-se uma estrutura lógica para apresentação do processo de modernização do Estado, conceituando a administração gerencial, caracterizando os efeitos do gerencialismo no setor público a partir da literatura e verificando a existência e ascensão do gerencialismo, tendo como instrumento o programa gerencial da empresa.

Percebeu-se nitidamente a presença e a ascensão do modelo gerencialista na empresa pública, objeto da pesquisa, que se caracteriza no alinhamento dos objetivos da empresa com os treinamentos oferecidos, utilizando recursos de uma empresa privada para dar os treinamentos com forte incentivo à cultura do management, onde é passado todo um discurso gerencialista de culto à excelência, orientação por mais comprometimento com a empresa, busca por maior produtividade focada no cliente e uso do poder para internalizar sua ideologia.

Observou-se que as quatro competências definidas pela organização - iniciativa, comprometimento, foco no cliente e trabalho em equipe, estão presentes nos cursos oferecidos. Essas quatro competências fazem parte do ideal pregado pela administração gerencial.

Os temas centrais do sítio vêm a corroborar todo um arcabouço gerencialista instalado na empresa. Ideologia do setor privado influenciando diretamente o setor público. 
Nota-se o treinamento gerencial sendo usado como instrumento para fortificar e disseminar os conceitos gerencialistas como verdades únicas a serem seguidas.

Os pressupostos gerencialistas estão presentes em todas as falas dos entrevistados: controle, sedução do discurso, a fascinação para com a organização, a servidão voluntária e o comprometimento.

Finalmente, confirma-se que o recurso humano na organização é um instrumento para se chegar a resultados.

Com base nessas constatações, cita-se Gaulejac (2007) que sugere uma forma de recuperar o sentido de viver, com novos valores da existência humana, um valor universal de solidariedade e respeito às pessoas e à natureza. Consiste na transformação do indivíduorecurso em indivíduo-sujeito, renunciar ao utilitarismo e optar em favor de um homem único e ao mesmo tempo ligado ao seu próximo, com desejo de realização e não de competição. Para o autor, o poder gerencialista deveria ter a preocupação com a livre circulação de mercadorias e capitais e, ao mesmo tempo, com a defesa do direito do trabalho e proteção social. A empresa deveria ser um meio de proporcionar bem-estar coletivo e não um meio em si mesmo.

$\mathrm{O}$ autor aponta a economia solidária como um caminho para o equilíbrio entre a economia, o social e o político. Nessa forma de gestão a ciência e a pesquisa são colocadas a serviço do bem comum e da demanda social mais do que a critérios de utilidade e lucratividade.

A compreensão de gestão não deve ser realizada por modelos teóricos inspirados nas ciências exatas, como o positivismo e o utilitarismo, e, sim, nas ciências sociais, já que a finalidade da empresa não é exclusivamente econômica e financeira, mas também humana e social. Assim, o trabalho não pode ser considerado unicamente sob o ângulo da produção e dos resultados, mas igualmente sob o ângulo do sentido da atividade, da subjetividade e da vivência, que são variáveis tão importantes quanto a produção e a rentabilidade. 
Dessa forma, a gestão recuperará a credibilidade que perdeu se puder trazer mais sentido e menos insignificância, mais compreensão e menos prescrição, mais análise qualitativa e menos medida quantitativa. Levando em consideração a capacidade reflexiva e decisória do seu recurso humano, que não pode trabalhar e viver sem dar sentido às suas ações e em si mesmo, apenas em nome da acumulação capitalista.

Paes de Paula (2006,p.178), chama a "atenção para a importância de se desenvolver experiências adequadas ao interesse público ao invés de imitar modelos padronizados gerados no âmbito empresarial.”. E “defende que a administração pública tem uma lógica própria, requerendo o desenvolvimento de técnicas de gestão adequadas, além de uma formação específica para os gestores públicos” (PAES DE PAULA, 2006,P.179).

Propõem-se estudos futuros seguindo a análise de Gaulejac e Paes de Paula, para uma nova gestão pública onde o servidor público seja valorizado e usado não como instrumento pra se obter resultados a qualquer preço, mas para cumprir cabalmente a natureza de seu trabalho, que é servir a sociedade com dignidade sem perder abdicar de sua vida. Essa gestão pública, que ainda está no sonho de concepção, possa entrar no estágio embrionário. 


\section{REFERÊNCIAS}

ABRUCIO, Fernando Luiz. Os avanços e os dilemas do modelo pós-burocrático. In: BRESSER-PEREIRA, Luiz Carlos; SPINK, Peter (Org.). Reforma do Estado e Administração Pública Gerencial. Rio de Janeiro: FGV, 2005. p.173-199.

BAUER, Martin W.; GASKELL, George. Pesquisa qualitativa com texto, imagem e som: um manual prático. Petrópolis, RJ: Vozes, 2002.

BRESSER-PEREIRA, Luiz Carlos; PACHECO, Regina Silvia. A reforma do Estado brasileiro e o desenvolvimento. In: Crise política e reforma das instituições do Estado brasileiro. Rio de Janeiro: José Olympio Editora, 2005. Disponível em:

$\leq$ http://www.bresserpereira.org.br/papers/2005/05.23.ReformadoEstadoBrasileiroeoDesenv olvimento.WEB.pdf $>$ Acesso em: 20 jan.2007.

Gestão do setor público: estratégia e estrutura para um novo Estado. In:

Reforma do Estado e administração pública gerencial. Rio de Janeiro: Editora Fundação Getúlio Vargas, 1998. Disponível em:

$\leq \mathrm{http}: / / w w w . b r e s s e r p e r e i r a . o r g . b r / p a p e r s / 1998 / 98-G e s t a o D o S e t o r P u b l i c o-$

Estrategia\&Estrutura.pdf $>$. Acesso em: 20 jan. 2007.

. Reflexões sobre a reforma gerencial brasileira de 1995. Revista do Serviço Público, São Paulo, n. 50, p. 5-30, out.1999. Disponível em:

$\leq$ http://www.bresserpereira.org.br/papers/1999/93.reflexoessobrereformagerencial.p.pg.pdf z. Acesso em: 20 jan. 2007.

CHANLAT, Jean - François. O gerencialismo e a ética do bem comum: a questão da motivação para o trabalho nos serviços públicos. In: VII Congreso Internacional del CLAD sobre la reforma del estado y de la administrácion publica, Lisboa: Anais. CLAD, 2002. p.1-9.

DAVEL, E.; MELO, M. C. O. L. (Orgs.). Gerência em ação: singularidades e dilemas do trabalho gerencial. Rio de Janeiro: FGV, 2005.

ENRIQUEZ, Eugéne. As Figuras de poder. Belo Horizonte: Via Lettera, 2007. 
FREITAS, Maria Estér de. Imaginário social e organizacional moderno, In.: Cultura Organizacional: identidade, sedução e carisma? 2. ed. São Paulo: Ed. FGV, 2000. cap.3.

GODOY, A. S. Introdução à pesquisa qualitativa e suas possibilidade. Revista de Administração de Empresas, São Paulo, V.35, n.2, p.57-63, mar./abr. 1995.

GAULEJAC, Vincent de. Gestão como doença social: ideologia, poder gerencialista e fragmentação social. São Paulo: Ed.

Idéias e Letras, 2007.

KETTL, Donald F. A Revolução Global: reforma da administração do setor público. In: BRESSER-PEREIRA,Luiz Carlos; SPINK, Peter (Org.). Reforma do Estado e Administração Pública Gerencial. Rio de Janeiro: FGV, 2005. p.75-121.

LÜDKE, M.; ANDRÉ, M. L. Pesquisa em educação: abordagens qualitativas. 6.reimp. São Paulo: EPU, 1986

MIRANDA JUCÁ, Maria Carolina. Crise e reforma do Estado: as bases estruturantes do novo modelo. 2002, p. 1-10. Disponível em

http://www.escritorioonline.com/webnews/noticia.php?id_noticia=2251\&. Acesso em $23 / 02 / 2009$

MOREIRA NETO, Diogo de Figueiredo. Administração Pública Gerencial. Revista de Direito Administrativo. Rio de Janeiro ,v 2, n. 4 , p. 37-44, jul./dez. 1998.

PAGÉS, Max. et al. O poder das organizações. São Paulo: Atlas,1987.

PASQUALI, L. Testes referentes a construto: teoria e modelo de construção. In:

PASQUALI, L. (Org.) Instrumentos psicológicos: manual prático de elaboração. Brasília: LabPAM; IBAPP, 1999, cap.3.

PAUlA, Ana Paula Paes de. Por uma nova gestão pública: limites e potencialidades da experiência contemporânea. Rio de Janeiro: Editora FGV, 2005

Entre o gerencialismo e a gestão social: em busca de um novo modelo para a administração pública brasileira. Disponível em: 
$\leq$ http://www.participacaopopular.org.br/textos/ana.paula.paes entre.o.gerencialismo.pdf $>$. Acesso em: 16 janeiro2009.

, Administração pública brasileira entre o gerencialismo e a gestão social.

Revista de administração de empresas (FGV), São Paulo, v.45, n.1, p.36-49, 2005b.

Disponível em:

$\leq$ http://www.ead.fiocruz.br/comunidade/politicasenap/downloads/administracaopublicabras ileiraentreogerencialismoea.pdf>. Acesso em: 13 dezembro2008.

, Administração pública gerencial: o novo papel do Estado na sociedade contemporânea, 2005. Disponível em:

$\leq \mathrm{http}: / /$ pascal.iseg.utl.pt/ portugalbrasil/files/ArtigoPortugal2005.pdf $>$ Acesso em: 16 janeiro 2008.

SIQUEIRA, Marcus Vinicius Soares. Gestão de pessoas e discurso organizacional: crítica à relação indivíduo-empresa nas organizações contemporâneas. Goiânia: Ed. da Universidade Católica de Goiânia, 2006.

SIQUEIRA, Marcus Vinícius Soares. O Imaginário organizacional moderno e o discurso do superexecutivo de sucesso nas organizações. In: Iberoamerican Academy of Management, São Paulo, 2003. Disponível em: $\leq$ http://www.fgvsp.br/iberoamerican/papers/00037 0\%20imaginario\%20organizacional $\% 20$ moderno $\% 20 \mathrm{e} \% 20 \mathrm{o} \% 20$ discurso $\% 20$ dopdf $>$. Acesso em: 13 dezembro 2008

VERGARA, Sylvia Constant. Começando a definir a metodologia. In: Projetos e relatórios de pesquisa em administração. 3.ed. São Paulo: Atlas, 2000. cap.4, p. 46-53.

Wikipédia. Disponível em http://pt.wikipedia.org/wiki/Administra\%C3\%A7\%C3\%A30. Acesso em 03 fev 2009

WOOD JR. Thomaz. Revista Carta Capital. A vida como extensão da empresa. São Paulo, 2008. P. 84-89.

ZANELLI, J.C. Pesquisa qualitativa em estudos da gestão de pessoas. Estudos da Psicologia, 7, 79-88, 2002. 